Torben Thrane*

\title{
Sikke et ord
}

\begin{abstract}
There is an apparently peripheral construction type that falls outside the normally mandatory V2-structure of Danish main clauses, expressions introduced by the emphatic lexical item sikke (plus inflectional variants sikken, sikket). Such expressions defy standard taxonomic descriptions of Danish and pose a challenge to current formal (GB/PP/ Minimalist) generalizations about movement operations. This paper aims to give not only a coherent description of such expressions in morphological, syntactic, and semantic terms, but also proposes a simple mechanism for information-sharing between nodes in addition to overt and - especially - covert movement. Given this mechanism it is shown that the description of a number of other and seemingly disparate aspects of Danish syntax follows naturally from the assumption that they are all instantiations of 'breakstructure'.
\end{abstract}

\section{Indledning}

Der er en distributionsklasse i dansk der kun har ét medlem - ordet sikke. Ordklassemæssigt kategoriseres det i diverse leksika og grammatikker som pronomen og/eller adverbium og/eller adjektiv. Det er klassifikationer der ikke enkeltvis yder det retfærdighed, men som tilsammen antyder en vis distributionel versatilitet. Derimod ser de bort fra dets interaktion med determinativsystemet, fra dets særlige semantiske egenskaber og (dermed) fra dets særlige kommunikative egenskaber. Og de tager slet ikke den udfordring op som ordet udgør for (formelle) beskrivelser af dansk.

* Torben Thrane

Engelsk Institut, Handelshøjskolen i Arhus

Fuglesangs Allé 4

DK-8210 Aarhus V

E-mail:tt@asb.dk 
Dette støttes af at udtryk med sikke normalt enten slet ikke omtales eller kun berøres meget kortfattet. ${ }^{1}$ Der turde således være tale om en 'perifer' konstruktionstype der formentlig falder uden for 'kernen' af dansk grammatik, og som man derfor kunne mene ikke burde skænkes megen opmærksomhed fordi beskrivelsen af den ikke vil bidrage til en nøjere forståelse af universalgrammatikken. Denne sejlivede grundantagelse er kommet under stærkt pres på det seneste, ikke blot fra funktionelt hold, men også fra formelt, f. eks. Culicover \& Jackendoff (1999) og Kay \& Fillmore (1999), der side 1, note 1 sætter dagsorden på denne vis: "The point here is that the construction grammarian" does not have the luxury of setting aside any specific piece of problematical data as irrelevant to grammatical theory".

Denne artikels hovedpåstand er at gængse (formal-)grammatiske beskrivelser på afgørende punkter ikke er rummelige nok til at redegøre for de særlige distributionelle, formelle og semantiske egenskaber ved udtryk indledt med sikke. Den tilstræber dernæst at bidrage med en sådan beskrivelse og diskuterer hvilke konsekvenser akcept af den vil have for den generelle beskrivelse af dansk. Teoretiske udsagn er konfronteret med data fra Bergenholtz DK87/90, der omfatter løbende moderne danske tekster på tilsammen ca. 4 mill. ord. Dette korpus danner ligeledes baggrund for sporadiske udsagn om statistiske tendenser. Eksempler hentet herfra er markeret med ' 0 '.

1 F.eks. nævner Allan et al. (1995:85) blot én type (se nedenfor) som genus- og numerusdifferentierede 'emphatic pronouns' i forbindelse med adjektivfleksion; Hansen (1980) giver kun et enkelt eksempel på en anden type under overskriften 'Helsætninger med nav', med kommentaren at "dette underskema blot forekommer $\mathrm{i}$ en række »udråbsagtige« udtryk med bare, gid, mon, sikke o.a. på førstepladsen" (p. 77). FischerHansen \& Kledal (1994:92) nævner kun samme type som Hansen, idet de til gengæld giver en kortfattet men god karakteristik af dens væsentligste egenskaber: "[sikke-udtryk] bruger man i talesproget når man vil fremhæve noget. Disse ord kan kun stå forrest $\mathrm{i}$ sætningen. Der er ikke inversion efter sikken+substantiv." Mikkelsen (1911:288) giver i en delvis sproghistorisk anmærkning etymologien af sikken som en sammentrækning af se hvilken, og henfører derfor sikken til de 'spørgende henvisningsord', med genus- og numerusforskelle; han nævner ligeledes at sikken undertiden bruges som biord.

2 Dvs. den grammatiker der forpligter sig til i princippet at give en udtømmende beskrivelse af samtlige konstruktionsmuligheder i et givet sprog. 


\subsection{Morfologi}

Sikke optræder i tre distinkte former:
a. sikke
b. sikken
c. sikket

(b) og (c) viser samme - $n /-t$ variation som den ubestemte artikel, mens (a) tilsyneladende snarere svarer til den bestemte flertalsartikel $d e$. Statistisk er der imidlertid ikke overensstemmelse imellem forekomsterne af artiklerne og formerne af sikke. Der er i DK87/90 blot én forekomst af sikket og 31 af sikken mod 120 af sikke. Dette harmonerer ikke med det statistiske forhold imellem singularis $(-n+-t)$ og pluralis NP, eller imellem utrum $(-n)$ og neutrum $(-t) \mathrm{N}$ på dansk. Der er i eksempelmaterialet 83 forekomster af en, 35 af et. Heroverfor er der blot 9 forekomster af $d e$. Selvom dette ikke er den eneste pluralismarkering af $\mathrm{N} \mathrm{i}$ dansk er det klart at balancen imellem pluralis og singularis snarere vil være den modsatte af hvad den er imellem sikke på den ene side, sikken/ sikket på den anden. Og dette hænger naturligvis sammen med det forhold at sikke ikke - i hvert fald ikke udelukkende - er en pluralismarkør.

Ej heller er det - udelukkende - en genusmarkør. Sikke optræder i forbindelse med singularis utrum-N i 49 tilfælde, i forbindelse med singularis/utælleligt neutrum-N i 30 tilfælde. At genuskongruens ikke er et fast fænomen $\mathrm{i}$ forbindelse med formerne af sikke generelt fremgår endnu mere slående af det faktum at sikken forekommer sammen med et i ikke færre end 7 tilfælde og sammen med noget i 1 tilfælde. Der er dog ingen forekomster af kombinationen sikket + en, en mulig kombination der her anses for ugrammatisk. Disse og andre forhold er genstand for nærmere diskussion nedenfor.

\subsection{Data}

For en rent observationel betragtning er der to hovedtyper af udtryk indledt med sikke:

(2) a. Sikke en fin cykel!

b. Sikke en fin cykel du har fået.

I (2)(a) er der umiddelbart tale om en konstruktion på fraseniveau, mens der i (2)(b) er tale om en sætningskonstruktion. Dette skel understreger at der er to sider af den syntaktiske analyse: en intern, der redegør for 
strukturen af udtryk af type (2)(a) og specielt hvilken kategori vi skal tilskrive dem, og en ekstern der redegør for funktionerne af udtryk af type (2)(a) når de indgår i udtryk af type (2)(b). Indtil videre vil jeg præanalytisk betragte udtryk af type (2)(a) som en endnu ikke nøjere specificeret frasetype (XP), udtryk af type (2)(b) som sætninger, og jeg vil omtale dem som hhv $X P$-udtryk og $S$-udtryk. Der kan skelnes yderligere imellem to arter af $S$-udtryk: infinite og finite sætningskonstruktioner. Blandt de finite er der dernæst et skel imellem dem der har sikke som selvstændigt, tilsyneladende blot adjungeret sætningskonstituent (adverbial) og dem der (som (2)(b)) har et 'helt' $X P$-udtryk som sætningsinitial konstituent. I både disse sidste og de infinite udgør $X P$-udtrykket tilsyneladende et syntaktisk led, typisk som objekt, men også som (indholds)subjekt, adverbial, og subjektsprædikat. Alle typer vil samlet blive omtalt som sikke-udtryk. Søgningen i korpus viste endvidere følgende 3 eksempler, der anses for ugrammatiske — i det mindste 'kreative' eller fejllæsninger af sikkert:

(3) a. ${ }^{\circ}$ Det glæder mig, at du sikke skal til at leve et løssluppent kunstnerliv, nu hvor du er alene.

b. ${ }^{\circ}$ Følelsesmæssige forhold bør ligge Dem varmt på sinde, og De høster sikken løn for en selskabelig charmeoffensiv.

c. ${ }^{\circ}$ Det skulle løse problemerne indtil videre, havde de sagt i socialforvaltningen og havde sikken været lettet over at få hende og Pauline anbragt et sted, hvor de kunne blive glemt indtil videre.

\subsection{Sikke-udtryk og Diderichsens satningsskema}

Eftersom $X P$-udtryk ikke umiddelbart er sætninger, kan vi ikke forvente at de skal kunne indpasses i Diderichsens scetningsskema. ${ }^{3} S$-udtryk, derimod, kan koordineres frit med helsætninger, som i

(4) ${ }^{\circ}$ Hun var en smuk kvinde, Mary, men sikke et kaos, der var i hende

\footnotetext{
Der er imidlertid eksempler på koordination imellem et $X P$-udtryk og såvel en ledsætning som en (udråbs)helsætning:

o Det kniber meget med at holde sammen på indholdet i gode bøger, hvorimod du begynder at synes om "Dallas", og sikke pæne damer.

${ }^{\circ}$ Hvor var hun dog smuk, og sikke en fin kjole og så videre og så videre.
} 
Hvis de ud fra dette kriterium akcepteres som helsætninger med XPudtryk som første konstituent burde de kunne indpasses i Diderichsens skema for danske hovedsætninger. Men det lader sig ikke gøre uden videre (smlg. også henvisningen til Hansen (1980) i fodnote 1):

\begin{tabular}{|l|l|l|l|l|l|l|}
\hline Fundament & $\mathbf{v}$ & $\mathbf{n}$ & a & V & N & A \\
\hline Sikke en fin cykel & $?$ & du & da & har fået & & \\
\hline En fin cykel & har & du & da & fået & & \\
\hline
\end{tabular}

$S$-udtryk er tilsyneladende ikke V2. Det hjælper naturligvis ikke at betragte sikke som første konstituent alene. Alternativt kunne $S$-udtryk ses som ledsætninger med et $X P$-udtryk i konjunktionalfeltet:

\begin{tabular}{|l|l|l|l|l|l|l|}
\hline Konjunktional & n & a & V & V & N & A \\
\hline Sikke en fin cykel & du & da & har & fået & & \\
\hline ...at & du & da & har & făet & en fin cykel & \\
\hline
\end{tabular}

Men denne løsning støder på flere vanskeligheder. For det første kan $S$ udtryk som nævnt koordineres med helsætninger. For det andet er det sjældent (men ikke umuligt -jf. Diderichsen, 1986:11) at konjunktionaler indeholder sætningsled som $S$-udtryk oftest gør det - i det aktuelle eksempel det direkte objekt. For det tredje kan $S$-udtryk iøvrigt ikke optræde som ledsætninger:

(5) a. *Jeg troede sikke en fin cykel han havde fået

b. *Jeg så (at) sikke en fin cykel han havde fået

Selvom $X P$-udtryk deler den topologiske egenskab med konjunktionaler at skulle stå i første position i sætningen de indgår i, deler de ikke den for konjunktionaler væsentligste egenskab at markere ledfunktion af den. Eneste undtagelse fra reglen om første position er at $S$-udtryk generelt tillader en foranståede sideordnende konjunktion ( og, men, for), ligesom indlejrede sætninger i øvrigt.

En tredje mulighed ville være at betragte $S$-udtryk som en særlig type $X P$-udtryk hvor nominalet i $X P$-udtrykket er postmodificeret af en relativsætning uden relativ:

(6) a. Sikke [en fin [cykel du har fået]]

I så fald skulle man forvente mulige udtryk som

b. *Sikke en fin cykel som du har fået

Det er der ikke umiddelbart belæg for i datamaterialet, og det må betragtes som ugrammatisk, i hvert fald i rigsdansk skriftsprog (dette spørgsmål 
tages dog op til revision i afsnit 3.4.1. og 3.5.1.). Denne løsning ville naturligvis heller ikke afhjælpe problemet med indpasning af $S$-udtryk i sætningsskemaet.

$S$-udtryk kan heller ikke være udtryk med $X P$-udtryk som 'Theme' i funktionel grammatisk forstand, for i givet fald skulle 'resten' af $S$ udtrykket udgøre en komplet sætning (Basbøll 1986:85). Men det gør den ikke:

a. Sikke en fin cykel han har fået

b. *Han har fået

Det ser m.a.o. ud til at sætningsskemaet i sin klassiske udformning ikke uden videre kan bruges som beskrivelsesgrundlag for $S$-udtryk. Jeg vil derfor $\mathrm{i}$ det følgende henholde mig til en diskussion af hvorvidt en generativ beskrivelsesmodel $\mathrm{i} \mathrm{GB/PP/Minimalist} \mathrm{traditionen} \mathrm{ville} \mathrm{kunne}$ bringes til at håndtere dem, og $\mathrm{i}$ givet fald hvordan. Lad os først se på den interne struktur og dermed kategoriseringen af $X P$-udtryk.

\section{2. $\quad X P$-udtryks interne syntaks og kategorisering}

$X P$-udtryk har klart karakter af udråb ( "Brand!") snarere end udsigelse ("Det brcender!'). Vi antager derfor indledningsvis at $X P$-udtryk udgør en form for nominal, hvilket indebærer at vi i det følgende vil undersøge hvilke(n) af de veletablerede nominalkategorier (NP, DP) $X P$-udtryk kan siges at udgøre en delmængde af. I de simpleste tilfælde består de blot af en form af sikke $+\mathrm{N}$. I de få tilfælde hvor der ikke er et leksikalsk N som konstituent er der en proform, enten en eller noget:

(8) a. ${ }^{\circ}$ Og der er en mand, nej, sikken en

b. $\quad$ Sikke da noget

Ellers er konstitutionen denne:
a. ${ }^{\circ}$ sikke barme!
b. $\quad$ sikken ædelse
c. ${ }^{\circ}$ sikket hastværk

Som det fremgår forekommer alle tre former af sikke i denne simple type, og en konservativ strukturel beskrivelse af den ville være flg.:

(10) $\left[_{\mathrm{NP}}\left[\left[_{\text {Det }} \text { \{sikke } \mid \text { sikken } \mid \text { sikket }\right\}\right]\right]_{\mathrm{N}}$ \{barme $\mid$ ædelse $\mid$ hastværk $\left.\left.\}\right]\right]$

Det har imidlertid siden Abney (1987) været standard at betragte determinativet som kernen i et (argumentativt) NP. En mere tidssvarende strukturel beskrivelse ville derfor se sådan her ud: 
(11) $\left[_{D P}\left[{ }_{D},\left[_{D}\{\right.\right.\right.$ sikke $\mid$ sikken $\mid$ sikket $\left.\}\right]\left[_{N P}\right.$ \{barme $\mid$ ædelse $\mid$ hastværk $\left.\left.\left.\}\right]\right]\right]$

DP er den maksimale projektion af den funktionelle kerne D, hvis leksikalske realisation er klassen af determinativer og som tager NP som komplement. (11) (såvel som (10)) rummer m.a.o. en forudsigelse om at sikke er et determinativ. Dette ville imidlertid skabe problemer for analysen af den hyppige $X P$-type der udover en form af sikke også indeholder et traditionelt determinativ, som i:

(12) a. Sikke en katastrofe!

b. $\quad$ Sikken en dag

De ville tilsyneladende snarere kræve en strukturel beskrivelse som flg. (sml. Radford 1993:91f):

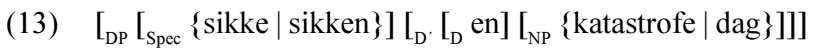

Katastrofe/dag udgør kernen i et NP der er komplement til en, kernen D i den funktionelle projektion DP med sikke som Spec(ifikator). 'Komplement' og 'specifikator' er funktionelle termer. Konfigurationen [HeadCompl] udgør den fundamentale relation i en X-bar teoretisk struktur, mens [Spec-Head] er sekundær og dermed undertiden valgfri (Chomsky 1995:172ff). Der er i øvrigt ikke enighed om hvad der kan fungere som specifikator (se f. eks. Radford 1997:90f, og Pollard \& Sag 1994:358ff). Betragt den her som blot en mulig strukturel position for maksimale projektioner der kan have grammatisk relation til kernen af forskellig art, herunder bl. a. den i vor sammenhæng væsentlige at determinere kongruens (såkaldt 'Spec-Head agreement').

Der er således i (13) ikke sagt noget om, hvilken kategori sikke(n) er tilskrevet. En nærliggende realisationsmulighed for [Spec, DP], anvist af den del af den grammatiske tradition der kategoriserer sikke som adverbium, kunne være som vist i (14), der samtidig beskriver de strukturelt set mest komplekse $X P$-udtryk der gives: 


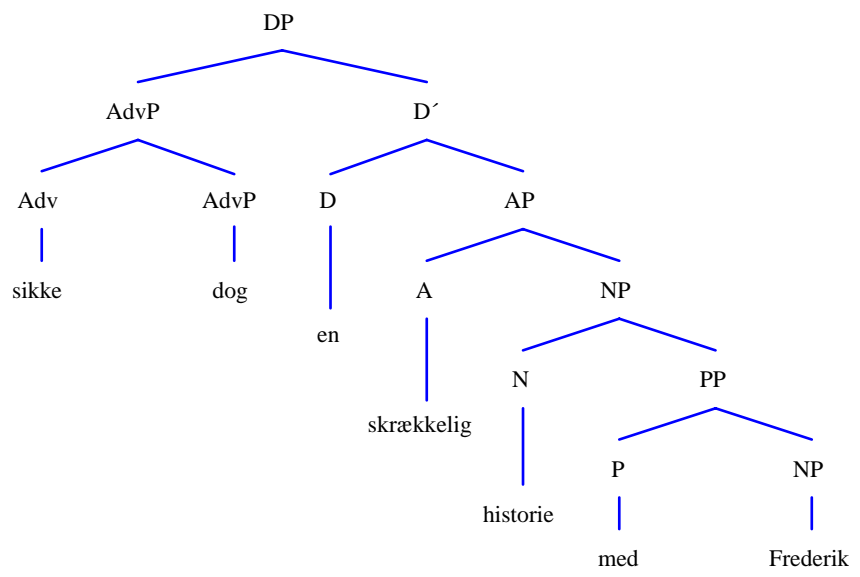

Her ligger uden videre diskussion den stærke begrænsning på antal og art af adverbium der kan følge sikke ( $d o g, d a, n u$, ellers) bag beskrivelsen af $d o g$ som komplement til sikke. Den beskrivelse vil imidlertid ikke blive opretholdt. Den indbyrdes orientering af AP og NP er fra Delsing (1993:81), der argumenterer for NP som 'højre-specifikator' i AP. ${ }^{4}$ Uanset om dette akcepteres eller ej, er der imidlertid en væsentlig grund til at (14) ikke umiddelbart kan være den rigtige repræsentationsform. Den kan ikke give nogen plausibel begrundelse for den formmæssige variation imellem sikke, sikken og sikket, en variation der normalt ikke findes ved adverbier, kun ved adjektiver og determinativer. Hvis vi ikke desto mindre akcepterer formmæssig variation blandt visse (typer af) adverbier, og

4 Dette synspunkt kunne anfægtes ud fra et overordnet hensyn til sprogtilegnelse. Det kan forekomme bemærkelsesværdigt, inden for rammerne af en teori der anser sprogtilegnelse for at være et spørgsmål om parameterindstilling, at en så kommunikativt hyppig konstruktionstype som $\mathrm{A}-\mathrm{N}$ i sin interne struktur skulle manifestere en rækkefølge der ikke har afsmittende effekt på andre parametriseringer af rækkefølgen imellem specifikator og kerne. Radford (1997: 528) taler da også om 'Specifier-first' og 'Specifier-last' sprog som om der her er tale om en typologisk vigtig parameter. Til fordel for Delsing taler imidlertid at attributive og prædikative adjektiver kan gives en uniform analyse m.h.t. kongruens, idet begge under de givne antagelser tilfredsstiller betingelserne for 'Spec-Head agreement'. Yderligere begrundelse for at følge Delsing på dette punkt gives i afsnit $\mathbf{3 . 5}$. 
hvis strukturen i (14) dermed var 'korrekt' på dette punkt, så skulle vi under sædvanlige antagelser forvente streng kongruens imellem sikke og det følgende determinativ under 'Spec-Head agreement'. Det har vi ikke, som allerede nævnt. Det kunne så skyldes enten at det ikke er det strukturelle 'Spec-Head' forhold der er styrende for kongruens ${ }^{5}$, eller at den type adverbium vi tilskrev sikke havde særlige egenskaber der gav sig udslag i andre strukturelle forhold end dem der er nedfældet i (14). Med henblik på at afgøre det undersøgte jeg de kombinationsmuligheder som datamaterialet rummer for sikke+determinativ/pronomen/adjektiv/ substantiv.

\subsection{Intermezzo: $X \boldsymbol{P}$-udtryks intuitive semantik}

Sammenfattende ser det ud til at skellet for sikke's kompatibilitet med et efterfølgende determinativ/ pronomen følger Milsarks (1977) skel imellem 'svage' og 'stcerke' determinativer. Den relevante forskel imellem disse to typer kan indfanges i form af et semantisk træk $[ \pm \mathrm{E}(\mathrm{ksistentiel})$ $\mathrm{P}($ ræsupposition)], således at de stærke er eksistentielt præsupponerende, de svage ikke. Dette skel vil blive uddybet i afsnit 3. nedenfor. Derudover kan sikke ikke kombineres med $\mathrm{N}$ præmodificeret af komparativt/ superlativt A. Lader man sig styre af de overordnede semantiske egenskaber ved hver af disse konstruktionstyper, kunne man nå frem til følgende karakteristik af sikke's intuitive semantik:

$X P$-udtryk er for en umiddelbar betragtning gradsudtryk (dvs af kategori Deg(ree)P(hrase)). Under forudsætning af at man af semantiske grunde kun kan have ét gradsudtryk pr. frase, forklarer det hvorfor de ikke er kompatible med komparativ- og superlativformer af adjektiver. $X P$-udtryk er desuden bestemte, specifikke og eksistentielt prcesupponerende. Derfor kan de ikke kombineres med stærke determinativer eller gives en generisk tolkning (se videre i afsnit 3.1.)

Disse intuitive semantiske egenskaber ved $X P$-udtryk kunne sammenfattes af termen situationsafhcengighed. Forudsætningen for vellykket kommunikativ brug af et $X P$-udtryk er at afsender står inde for

5 I islandsk er det således tilsyneladende kasus-tilskrivningsegenskaber der styrer kongruensforhold. Sigurðsson (1996) søger at vise hvordan en strukturel 'Spec-Head' analyse kan generaliseres også for islandsk inden for rammerne af minimalistisk teori. 
forekomsten af en situation hvis delvise konstitution $X P$-udtrykket åbenbarer for modtager. $X P$-udtrykket vil da rumme en instruktion om at fokusere på bestemte entiteter i situationen og tilskrive dem en større eller mindre værdi end normen for den pågældende entitet, afhængigt af kontekstuelle forhold. Det er f. eks. ikke muligt endegyldigt at afgøre uden situationskontekst om vejret er godt eller skidt når man blot hører $X P$-udtrykket Sikket vejr, hva'!, kun at afsender anser det for enten bedre eller værre end man skulle forvente (for årstiden, stedet, tidspunkt på døgnet, ...). Ikke desto mindre ville det formentlig være korrekt at hævde, at den umarkerede tolkning af $X P$-udtryk er positiv, altså fremhæver en højere grad end forventeligt. Udtrykket ${ }^{\circ}$ Sikke barme! beder modtager acceptere afsenders vurdering af de omtalte attributter som 'mere barm' end det modsatte (hvad det end måtte være). At afsender 'står inde for' forekomsten af en situation vil normalt betyde at han/hun selv er eller har været en del af den. Afsender af udtrykket $\mathrm{i}{ }^{\circ}$ Sikke en brudenat! bør være enten brud eller gom. Enhver anden ville blive anset for utilbørligt nyfigen (hvilket i det aktuelle tilfælde passer udmærket, da der er tale om en billedtekst fra $\mathrm{Se} \& \mathrm{H} ø r)$.

Jeg betragter denne karakteristik af $X P$-udtryks semantik som intuitiv i den forstand at forståelsen af den — udover generel akcept af sproglig betydning som grundlæggende instruktionel — ikke synes at forudsætte noget større teoretisk apparat. Den er imidlertid næppe heller korrekt.

\subsection{Er XP-udtryk gradsudtryk?}

Det er væsentligt at fastholde at sikke kan 'modificere' situationelle fænomener der er udtrykt ved alle leksikalske klasser, bortset fra præpositioner $^{6}$ (selv når de introducerer et prædikativt led):

(15) a. ${ }^{\circ}[$ sikke fester] vi ku holde $(\mathrm{N})$

b. ${ }^{0}$ [sikke nysgerrig] du dog er (A)

c. ${ }^{0}[$ sikke ... [hun kunne] ...skrubbe] $(\mathrm{V}$ - og dermed hele S)

d. ${ }^{O}[$ sikke godt $]$ det var gået (Adv)

e. $\quad *[$ sikke $p a ̊$ bordet] lampen stod $(\mathrm{P})$

6 Dette er det normale forhold. I få semi-idiomatiske konstruktioner kan man f. eks. finde med som (usædvanlig) partitiv markør, eller $i$ som abstrakt lokativ: sikke med penge han bruger på nettet; sikke $\boldsymbol{i}$ valten han er. 
Dette er ikke en evne sikke deler med andre gradsmarkører, der traditionelt kategoriseres som A eller Adv. Vi har netop afvist at betragte sikke som ('almindeligt') adverbium ud fra kriteriet om formvariation, men da adjektiver varierer formmæssigt er sikke måske et 'gradsadjektiv'? Noget tilsvarende kunne gælde sådan (se (23)). En systematisk sammenligning af udvalgte gradsmarkørers topologi viser dette mønster:

\begin{tabular}{|c||c|c|c|c|}
\hline & (a) D Deg A N & (b) D N Deg A & (c) Deg A D N & (d) Deg D A N \\
\hline \hline så & + & + & + & - \\
mere & + & + & - & - \\
meget & + & - & - & - \\
sikke & - & - & + & + \\
sådan & - & - & - & + \\
\hline
\end{tabular}

Tabuleringen er en generalisering over data som disse:

(17) a. en så velholdt bil

b. en bil så velholdt

c. så velholdt en bil

d. *så en velholdt bil

(18) a. en mere velholdt bil

b. en bil mere velholdt ${ }^{7}$

c. *mere velholdt en bil

d. *mere en velholdt bil (mere $>>$ snarere)

(19) a. en meget velholdt bil

b. *en bil meget velholdt

c. *meget velholdt en bil

d. *meget en velholdt bil

(20) a. *En sikke velholdt bil

b. *En bil sikke velholdt

c. Sikke velholdt en bil ${ }^{8}$

d. Sikke en velholdt bil

(21) a. *en sådan velholdt bil

b. *en bil sådan velholdt

c. *sådan velholdt en bil

d. sådan en velholdt bil

$7 \quad$ Kræver korrelat med end: en bil mere velholdt end Sørens

8 Ikke belagt, men mulig: Sikke fornem en velkomst han fik er OK 
Delsing (1973:93ff) foreslår en generel struktur for gradsudtryk, med DegP indlejret i DP:

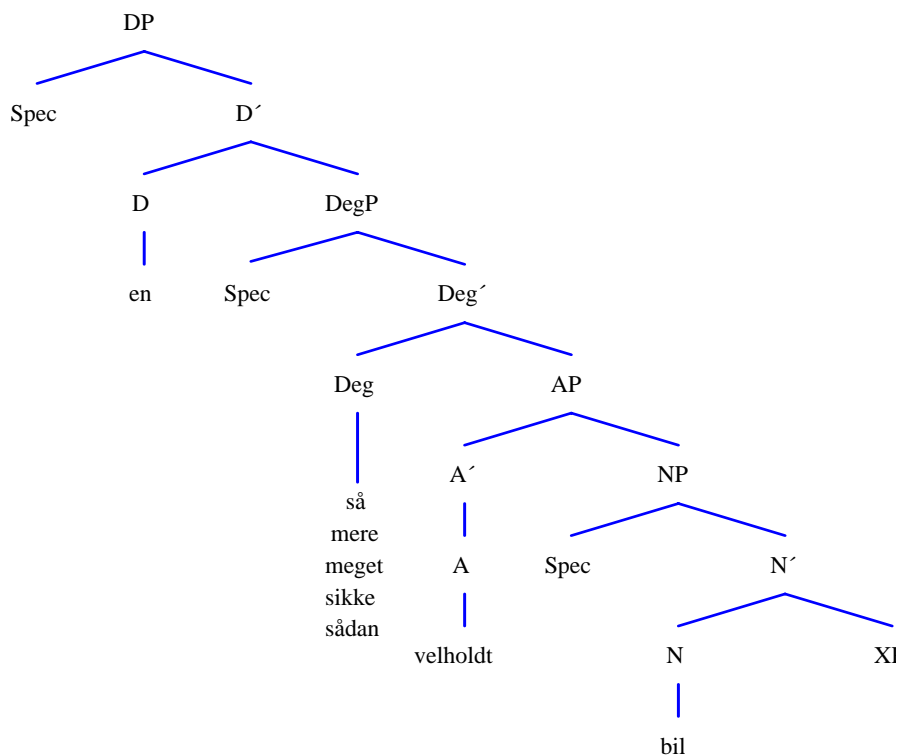

Som det fremgår gør (22) ligefremt rede for de grammatiske (a)-eksempler i (17)-(21), men den måtte så udelukke de ugrammatiske (a)-eksempler og forklare de grammatiske (d)-eksempler med sikke og sådan ved obligatorisk flytning af Deg til [Spec,DP]. Dette er teoretisk suspekt, da der ikke ville være tale om 'Head-to-Head movement', men om flytning af en kerne til en maksimal position. Ej heller vil den uden videre kunne redegøre for de grammatiske (c)-eksempler med så og sikke, men måtte akceptere enten at NP kan have den ubestemte artikel som specifikator, eller at så og sikke kan tage enten NP eller DP som komplement, hvor realisation af D i DP endvidere måtte være begrænset til den ubestemte artikel.

Bemærk også at sådan grammatisk kan optræde efter artiklen, men helst hvis der ikke er et attributivt adjektiv. I sådanne tilfælde udviser sådan streng genus- og numeruskongruens: 
(23) i. a. en sådan bil har jeg aldrig før kørt i

b. = sådan en bil har jeg aldrig før kørt i

ii. a. et sådant spektakel har jeg aldrig før hørt

b. = sådan et spektakel har jeg aldrig før hørt

iii. I sådanne tilfælde udviser sådan streng kongruens

- i det mindste i skriftsproget. Under Delsings analyse bliver der således tale om 'Spec-Head agreement'. Forekomsten af sådan efter artiklen kan naturligvis forklares med henvisning til den (semantiske) omstændighed at det leksikalsk set er generisk (= samme slags bil) og derfor kun kan selektere NP (og ikke AP). I sjældne tilfælde kan denne restriktion dog tilsyneladende ophæves. I så fald kan der kun være tale om modal betydning:

(24) a. jeg har aldrig før spist et sådant tilberedt måltid

b. jeg har aldrig før spist en sådan stegt bøf

- hvor sådan $(t)$ = 'på den måde'. Hvis denne formvariation er genusbaseret, har vi et tilfælde af et genusmarkeret adverbium, eller i det mindste genusmarkeret adverbiel funktion. Hvis omvendt $-t$ i (24)(a) blot er sædvanlig adverbiumsmarkering burde vi også finde den i (24)(b).

Udover de allerede nævnte forskelle, herunder den sædvanlige at sikke kun kan forekomme sætningsinitialt mens alle de andre gradsmarkører kan forekomme stort set overalt, er der ét gennemgående træk der adskiller de grammatiske sikke-eksempler fra alle de øvrige. Der kan, uden prosodiske brud af nogen art, indsættes et $d o g$ efter sikke - det kan der ikke efter nogen af de øvrige.

Konklusionen her må være at selvom sikke intuitivt er en gradsmarkør så er den ikke indlejret i DP med samme syntaktiske derivation eller samme slags semantik som andre gradsmarkører, uanset om de måtte være adverbier eller adjektiver. Vi vender tilbage til dette spørgsmål i afsnit 3.1.

\subsection{Er XP-udtryk bestemte og/eller specifikke?}

Som nævnt ovenfor kan der indgå ubestemte ('svage') determinativer og kvantorer i $X P$-udtryk. Der er nogle få udtrykstyper i dansk der tilsyneladende kombinerer bestemthed og ubestemthed, f.eks.

(25) a. disse mange mennesker er samlet her for at hylde hende

b. de få mønter han havde rakte ikke langt

c. det lidt vand som er tilbage (må vi spare på) 
I ingen af disse kontekster indgår sikke i paradigmatisk opposition med de bestemte determinativer:

(26) a. *Sikke mange mennesker er samlet her for at hylde hende

b. *Sikke få mønter han havde rakte ikke langt

c. *Sikke lidt vand som er tilbage (må vi spare på)

Ikke desto mindre er $X P$-udtrykkene i (26) forventelige — i og med at determinativerne efter sikke er svage - og man kan da også revidere (26) på en måde så de indgår i fuldt grammatiske $S$-udtryk:

(27) a. Sikke mange mennesker der er samlet her for at hylde hende

b. Sikke få mønter han havde. De rakte ikke langt

c. Sikke lidt vand der er tilbage. (Det må vi spare på)

Det er klart at sikke ikke kan være anaforisk. I givet fald skulle (26) være mulige. Hvis det er bestemt, må det således være deiktisk. Det ville harmonere med den overordnede karakteristik af det som situationsafhængigt. Jeg sagde tidligere at sikke fremhæver en eller flere entiteter i den situationelle kontekst som det beder modtager fokusere på. Men dette er ikke præcist nok - sml. (15). Det er ikke entiteter, sikke fremhæver, men hvad jeg med en noget vag terminologi blot vil kalde (situationelle) trcek. Det er tænkt som en gengivelse af den term Strawson (1959:202ff) bruger i forbindelse med diskussionen af 'feature-placing statements'. Dette er præcis hvad sikke's centrale semantik drejer sig om. Sikke er ekspressivt i den forstand at det udtrykker talers vurdering af, at et bestemt universelt træk er 'partikulariseret' i den umiddelbart givne situation. Der er tale om henledning af modtagers opmærksomhed på en egenskab, ikke på et (eller flere) individer som bærere af egenskaber. Sikke individualiserer egenskaber og gør dem tilgængelige som diskursreferenter. I denne forstand er sikke bestemt. I denne forstand er sikke ligeledes specifikt.

Dette underbygger yderligere den tidligere dragne konklusion at $X P$ udtryk ikke kan være DP'er. Det kan kun argumentative nominaler være. De har den særlige semantiske opgave at henlede opmærksomheden på individer som bærere af egenskaber.

Vi synes at være havnet $i$ en blindgyde. På trods af at $X P$-udtryk undtagelsesløst indeholder N (eller en proform — sml. (8) og (9)), lader de ikke til at være hverken NP eller DP, de kategorier der (på et eller andet niveau) har $\mathrm{N}$ som leksikalsk kerne. Ej heller kan de uden videre betragtes som AdvP med sikke som kerne. Spørgsmålet melder sig om de i det 
hele taget er konstituenter. Dette kan imidlertid ikke afgøres ud fra sædvanlige kriterier om flytning og substitution, for der er ingen steder de lovligt kan flytte $t i l$, og der er ingen udtryk de lader sig substituere med, hverken i $X P$-udtryk eller i $S$-udtryk. Men det kunne muligvis afgøres ved at studere hvilke konsekvenser det vil have for analysen af $S$-udtryk at betragte det initiale $X P$-udtryk som en konstituent.

\section{S-udtryks syntaks}

I et $S$-udtryk som

(28) Sikke en fin cykel han har

er det nærliggende at betragte det initiale $X P$-udtryk sikke en fin cykel som objekt for har og således tilskrive (28) denne struktur:

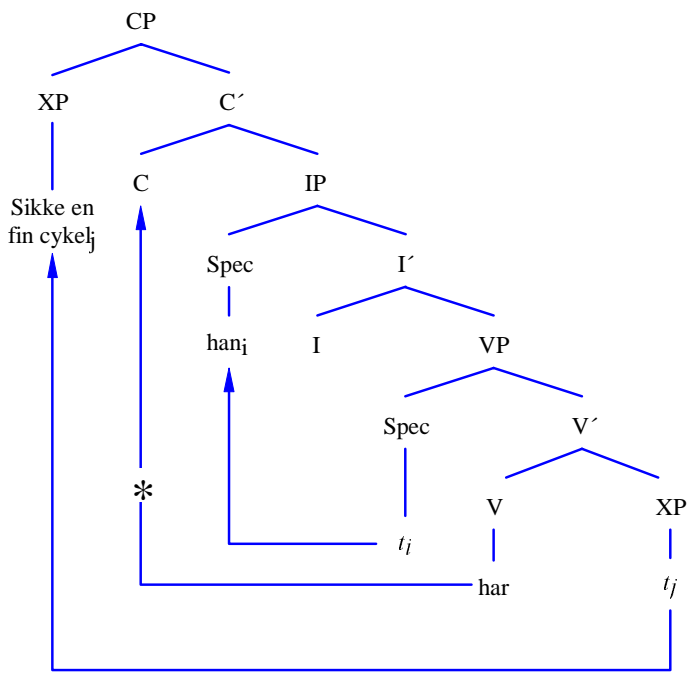


Det ville være en normal derivation under den antagelse at $X P$-udtryk var en særlig slags $H V$-udtryk, og at der således blot var tale om en form for operator-flytning. Men der kan sættes flere spørgsmålstegn ved den. ${ }^{9}$

Vi har for det første allerede fastslået at $X P$-udtryk ikke falder under en kendt kategori (AdvP, NP, DP) som kunne betragtes som [ $\mathrm{V}^{\prime}$,Compl], så værdien af XP er ukendt. For det andet er spidspositionen af sikke kompromisløs, selv i ekko-spørgsmål der efterlader $H V$-udtryk in situ og derfor normalt tjener som hovedargument for operator-flytning i det hele taget:

(30) a. Han har HVILKEN cykel?

b. *Han har SIKKeN cykel.

Det afgørende er imidlertid at der i (29) ikke er nogen strukturel grund til at S-udtryk ikke skulle vare V2! Som det fremgår ville har (eller have, hvis man går ud fra at fleksionsmorfologi genereres som funktionelle kerner hvortil verbalstammen knyttes ved adjungering) uproblematisk kunne undergå den obligatoriske flytning til $C$ som påstås at ligge bag de skandinaviske sprogs karakteristiske hovedsætningsordstilling med V2. Det ville give os

*Sikke en fin cykel har han

- der i alle måder ville leve op til normal dansk ledstilling i fremsættende hovedsætninger, men som altså er ugrammatisk. Den umiddelbart mest indlysende beskrivelse af $X P$-udtryk som konstituenter i $S$-udtryk er således ikke tilgængelig. Men der er andre muligheder.

Allerede Erik Hansen antyder en mulig løsning i bemærkningen citeret i fodnote 1. Her slås sikke sammen med bare, gid, og mon som en gruppe

$9 \quad$ Et af dem kunne vedrøre den påståede I-knude. INFL (IP) — den tidlige funktionelle kategori i GB/PP til styring af (endnu tidligere) AUX-træk - er i minimalistisk teori 'splittet' imellem en T(ense) P(hrase) og en funktionel kategori til styring af subjektverbum kongruens, $\operatorname{Agr}_{S} \mathrm{P}$. (Desuden antages der en $\mathrm{Agr}_{\mathrm{O}} \mathrm{P}$ til styring af verbum-objekt kongruens hvor dette er relevant — smlg. Chomsky 1991). INFL er i flere henseender en afvigende kategori (smlg. Chomsky 1986), og den anses af mange for suspekt i dansk i det hele taget - smlg. Heltoft (1999). Ikke desto mindre vil jeg fastholde den som forudsætning for tilstedeværelse af den (nødvendige) Spec-position hvori subjektet under gængse antagelser chekkes for kasus. Desuden er der i moderne dansk talesprog en tendens til 'hovedsætningsordstilling' i underordnede sætninger, som f. eks. 'han sagde at han kunne ikke komme'. Uanset om dette anses for en ønskværdig udvikling eller ej vil den kunne forklares under henvisning til udnyttelsen af en (i øvrigt) latent I-knude. Spørgsmålet om 'Split INFL' er, så vidt jeg kan se, ikke relevant for vort forehavende. 
af småord der introducerer 'udråbsagtige udtryk'. Eksplicit foreslår Vikner $(1995: 45 ; 1999: 94)$ at alle disse optræder $\mathrm{i}^{\circ 10} \mathrm{i}$ hovedsætninger, hvilket skulle begrunde hvorfor der ikke i sætninger indledt med dem er V2. Desuden opfører de sig ens i forhold til ét af de punkter jeg anser for kriterielle, idet de uden prosodisk brud tillader et umiddelbart følgende dog:
a. Bare dog han fik en fin cykel
b. Gid dog han fik en fin cykel
c. Mon dog han fik en fin cykel
d. Sikke dog en fin cykel han fik

Men derudover er der ikke parallellitet imellem de fire, hverken strukturelt eller selektivt/semantisk:

(33) a. Bare han fik en fin cykel

b. Gid han fik en fin cykel

c. Mon han fik en fin cykel?

d. *Sikke han fik en fin cykel (> Sikke en fin cykel han fik)

Hvor der i (a-c) er SVO er der i (d) OSV-følge. $S$-strukturer der ville opfange denne forskel er:

$$
\begin{aligned}
& \text { a. } \quad\left[_ { \mathrm { CP } } [ { } _ { \mathrm { C } } \text { bare|gid|mon } ] \quad \mathrm { I } _ { \mathrm { IP } } [ _ { \mathrm { DP } } \text { han } _ { \mathrm { i } } ] \quad \left[_{\mathrm{VP}}\left[_{\mathrm{DP}} t_{i}\right]\right.\right. \\
& \left.\left.\left[{ }_{\mathrm{V}},\left[{ }_{\mathrm{V}} \text { har }\right]\left[_{\mathrm{DP}} \text { en fin cykel }\right]\right] 1\right]\right] \\
& \left.\left.\left.\left[{ }_{\mathrm{V}},[\mathrm{V} \text { har }]\left[_{\mathrm{DP}} t_{i}\right]\right]\right]\right]\right] \\
& {\left[_ { \mathrm { IP } } [ _ { \mathrm { DP } } \text { en fin cykel } { } _ { \mathrm { i } } ] \left[_{\mathrm{VP}}\left[_{\mathrm{DP}} \text { han }\right]\right.\right.}
\end{aligned}
$$

I (34)(a) er der tale om en normal derivation, hvor subjektet (han) er flyttet til [Spec,IP] for at få chekket nominativ kasus af I. ${ }^{11}$ I (34)(b) derimod er det objektet (en fin cykel) der er flyttet til [Spec,IP]. Men det kan ikke lade sig gøre da objektet allerede er chekket for akkusativ af V. Der er ganske vist ingen formel indikation af det i dansk, og da der ikke kan forekomme former af det personlige pronomen i denne position efter

${ }_{10} \mathrm{C}^{\circ}$ er landingsplads for det finite verbum i hovedsætninger og for underordnende konjunktioner i ledsætninger. ODS's etymologiske beskrivelser af bare, gid, mon og sikke giver en plausibel diakron opbakning til forslaget om at indsætte dem netop i $\mathrm{C}^{\circ}$ : bare klassificeres i den relevante betydning som konjunktion, gid som (optativt) adverbium dannet ved sammentrækning af (Gud) give det (at), mon som en 'størknet' adverbiel form af et tidligere modalverbum monne og sikke(n) som pronomen udviklet ved sammentrækning af se hvilken.

11 Jeg antager m.a.o. den såkaldte 'VP-interne hypotese', der siger at subjektet basisgenereres i [Spec,VP]. 
sikke, er der ingen mulighed for at efterprøve det. Ikke desto mindre må vi antage at (34)(b) er en ulovlig struktur.

Man må derfor søge andre årsager til at [en fin cykel] er flyttet. For eksempel kunne man, evt. under henvisning til sikke-udtryks perifere karakter, påstå at der i $\mathrm{C}^{\circ}$ basisgenereres et sæt ('stærke') grammatiske træk der realiseres fonologisk som sikke og som (derfor) kræver flytning af objektet. Men man måtte så — for at undgå slækkelse af kravet om at kerner er 'ord' og ikke fraser - antage en struktur hvori [en fin cykel] er venstre-adjungeret til IP:

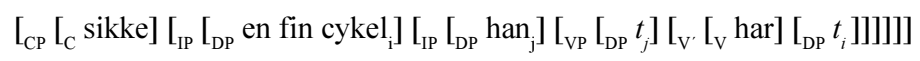

Dette ville være i overensstemmelse med standardanalyser af topikalisering (se Boškoviè 1997: 30ff, og for argumenter imod, Vikner 1995:100ff). Dermed er det fastlagt at [sikke en fin cykel] ikke er en konstituent. Til gengæld ville det være ganske ad hoc, og det vil fortsat være uforklaret hvorfor der er formmæssig interaktion imellem sikke og den efterfølgende ubestemte artikel, herunder den omstændighed at det skal være den $u$ bestemte artikel; og det ville være uforklaret hvorfor $X P$-udtryk ikke kan tolkes generisk.

\subsection{Intermezzo: $\boldsymbol{S}$-udtryks intuitive semantik}

Udover de ovennævnte strukturelle og ordstillingsmæssige forskelle imellem $S$-udtryk på den ene side og udtryk med bare, gid, mon på den anden, er der forskelle imellem dem af semantisk art.

For det første er der forskel m.h.t. 'bestemthedsklausulen' (Milsark 1977):
a. Bare han fik den cykel
b. Gid han fik den cykel
c. Mon han fik den cykel?
d. *Sikke den cykel han fik

Hvor sikke ikke tillader bestemthed i en efterfølgende NP gælder ingen tilsvarende begrænsning for de tre øvrige.

For det andet tillader sikke-udtryk som nævnt i 2.1. ikke generisk tolkning. Her er det dog nødvendigt at skelne imellem $X P$-udtryk og tilfælde hvor sikke er selvstændigt adverbium:

(37) a. sikke folk opfører sig tåbeligt

b. sikke folk der opfører sig tåbeligt (kan ikke tolkes generisk) 
I udtryk som (a) har sikke samme potentiale som bare, gid og mon m.h.t. generisk tolkning af en følgende NP, idet der i kraft af deres modalitet vil være forskelle i det følgende verbalkompleks:

(38) a. Bare folk ville opføre sig ordentligt!

b. Gid folk ville opføre sig ordentligt!

c. Mon folk ville opføre sig ordentligt (hvis...?)

Forskellen imellem (37)(a) og (b) tages som udtryk for at [sikke folk] i (b) er én konstituent, mens [sikke] og [folk] i (a) er to.

Delvis knyttet til det forrige punkt er der en struktur-semantisk forskel, idet sikke - som nævnt i fodnote 6 - lader sig kombinere med en eksplicit partitiv struktur i form af idiomatisk anvendelse af den sædvanligvis komitative præposition med. At det netop er en effekt af tilstedeværelsen af sikke turde fremgå af, at også (e) er ugrammatisk:
a. Sikke med mennesker der var i parken i går
Sikke der var med mennesker i parken i går
b. *Bare med mennesker der var i parken i går
*Bare der var med mennesker i parken i går
c. *Gid med mennesker der var i parken i går
*Gid der var med mennesker i parken i går
d. *Mon med mennesker der var i parken i går
*Mon der var med mennesker i parken i går
e. *Med mennesker der var i parken i går
*Der var med mennesker i parken i går

For det fjerde er der en markant forskel i de fire 'småords' kompatibilitet med negation:

(40) a. Bare (ikke) han (ikke) fik en cykel

b. Gid $(* i k k e)$ han ikke fik en cykel

c. Mon (ikke) han (ikke) fik en cykel?

d. Sikke (*ikke) en cykel han ('ikke) fik

Mens bare og mon tillader en efterfølgende negation $\mathrm{i}$ to forskellige positioner, gør gid og sikke det kun i én, og for sikke's vedkommende ikke semantisk lykkeligt. Det skyldes sikke's iboende præsupposition af et situeret træk. Det fremgår i forbindelse med verber med negativ polaritet, som i:

${ }^{\circ}$ sikke en masse renter han ellers ville gå glip af 
Her forudsættes den situationelle eksistens af trækket 'rente' - men manifesteret i renter han ikke ville få. På samme måde forudsætter (40)(d) den situationelle eksistens af trækket 'cykel', manifesteret i én som han altså desværre ikke fik. På trods af den let anstrengte semantik er der imidlertid ingen tvivl om at $i k k e$ kun ville kunne forekomme umiddelbart foran fik, og ikke umiddelbart efter sikke.

Der knytter sig yderligere en strukturel spidsfindighed til negationen af bare og mon-udtryk. Nægtelsen ikke kan sædvanligvis uden videre 'præmodificeres' af slet i såvel hoved- som bisætninger:

(42) i. a. Han vil slet ikke have en cykel

b. Vil han slet ikke have en cykel?

ii. $\quad$...at han slet ikke vil have en cykel

Antages det, som det undertiden gøres, at nægtelsen er kerne i sin egen funktionelle projektion der er knyttet til VP ved venstre-adjungering, kunne (42) forklares ved at betragte slet som specifikator i NegP. Det er nu bemærkelsesværdigt at kun den sidste af de to mulige positioner for nægtelsen efter bare og mon tillader en sådan specifikation:

(43) i. a. Bare han slet ikke fik en cykel

b. Mon han slet ikke fik en cykel?

ii. a. Bare (*slet) ikke han fik en cykel

b. Mon (*slet) ikke han fik en cykel?

Den simpleste forklaring på dette fænomen i forhold til (42) er at positionen for nægtelsen i (43) (ii) ikke er en NegP men blot en minimal projektion, NegE, hvis realisation kun kan være $i k k e^{12}$. Det synes yderligere at understøttes af at andre negationer, f. eks. aldrig, sjoldent, osv, så vidt jeg skønner heller ikke ville kunne optræde i første negationsposition, kun i den anden, VP-adjungerede.

En femte systematisk forskel er tilstedeværelse kontra fravær af semantisk sensitivitet $\mathrm{i}$ forhold til evt. attributive adjektiver:

(44) a. Bare han fik en \{fin $\mid$ blå $\mid$ ny $\mid$ italiensk\} cykel

b. Gid han fik en \{fin | blå $\mid$ ny | italiensk\} cykel

c. Mon han fik en \{fin $\mid$ blå $\mid$ ny $\mid$ italiensk \} cykel?

d. Sikke en $\{$ fin $\mid$ blå $\mid$ ?ny $\mid *$ italiensk $\}$ cykel han fik

12 Der er muligvis her tale om en yderligere kategori der - ligesom klitiske partikler kræver 'dobbelt klassifikation' som både Xºg XP, som foreslået af Chomsky (1995:249). 
Hvor sikke har skopus over (AP i) objektet har de andre tre det ikke, i det mindste ikke med samme konsekvenser. Skønt vi afviste sikke som gradsudtryk indlejret i DP, illustrerer (44)(d) at sikke fremtvinger en deskriptiv tolkning af A og ikke tillader en kategoriserende, et træk det deler med gradsudtryk som meget, mere og komparativ. Vi fastholder således sikke som gradsudtryk, men hævder at dets derivationelle syntaks adskiller sig fra andres.

\subsection{Derivationen af bare-, gid-, mon- og sikke-udtryk}

Det er nærliggende, specielt ud fra de observationelle facts under (32), (37)-(38), (39), (40), (42)-(44), at påstå en grundlæggende forskellig strukturel beskrivelse af gid-og sikke-udtryk på den ene side, bare- og mon-udtryk på den anden, om end med et vist overlap. Men selvom Vikner måske således kun delvis har ret $\mathrm{i}$ at disse fire småord optræder $\mathrm{i}$ $\mathrm{C}^{\circ}$, er der ingen tvivl om at de alle befinder sig højt oppe i den hierarkiske struktur. Spørgsmålet er hvordan den øverste, funktionelle, del af strukturen ser ud. Det antages normalt at danske (og andre V2-sprogs) deklarative hovedsætninger er CP'er, mens f. eks. engelske er IP'er. Det betyder at CP er topknude i strukturelle beskrivelser af danske ligefremt fremsættende sætninger, mens IP tilsvarende er det for engelske. Til beskrivelse af engelsk er CP derimod tilsyneladende kun nødvendig ved WH-spørgsmål, der involverer operator-flytning af WH-konstituenten til [Spec, CP].

Der er imidlertid an anden konstruktionstype i engelsk der også undertiden formodes substantielt at udnytte $\mathrm{CP}$, nemlig topikalisering. Radford (1997:312-3) skitserer tre forskellige strukturmuligheder for topikalisering:

a.

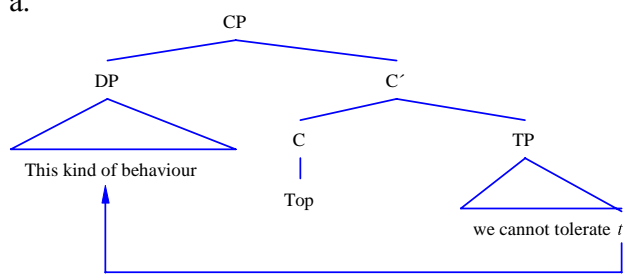

Sætningen er stadig en $\mathrm{CP}$, men der påstås en abstrakt leksikalsk kerne, Top. 
b.

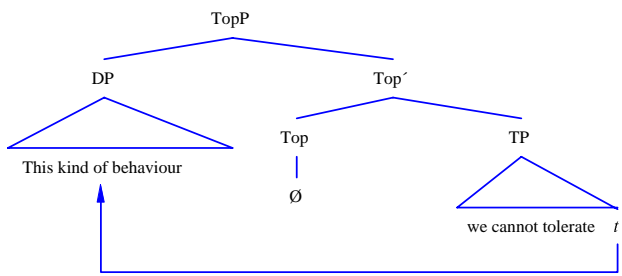

c.

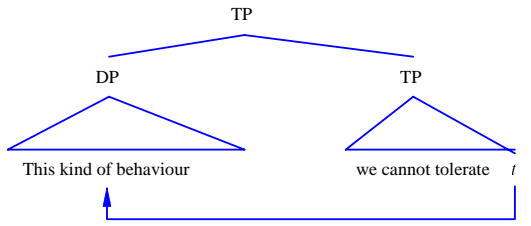

Sætningen er rekategoriseret som TopP, den maksimale projektion af en abstrakt leksikalsk kerne, Top.
Sætningen er rekategoriseret som $\mathrm{T}($ ense)P(hrase), og den topikaliserede konstituent er adjungeret hertil.

I alle tre tilfælde er det topikaliserede element DP — objekt for tolerate. I (a) og (b) er det flyttet til specifikatoren for den relevante topknude, i (c) adjungeret til den. Der er i den aktuelle engelske sætning

(46) a. This kind of behaviour we cannot tolerate

reelt ikke tale om anden operation end den der karakteriserer hovedsætninger i V2 sprog som dansk, nemlig muligheden for at spidsstillle en hvilken som helst (infinit) konstituent:

b. Den form for opførsel kan vi ikke tolerere

Der er naturligvis intet i vejen for at hævde at der også i dansk er tale om topikalisering i sådanne tilfælde, men det er ikke nogen operation der kræver andet maskineri end det der skal bruges til beskrivelsen af alle danske hovedsætninger. Så skønt der er tale om kommunikativ (funktionel) topikalisering er der ikke tale om en strukturel. Denne distinktion uddybes i afsnit 3.5.1. Man kan derfor uden videre akceptere (45)(a) som den mest generelle beskrivelsesmodel for topikaliseringer i engelsk. ${ }^{13}$

13 Jeg ser bort fra (45)(c) — der af Radford tillægges Jane Grimshaw i to ikke-publicerede mss. - ud fra den betragtning at rekategoriseringen af S til TP i stedet for CP ville vanskeliggøre beskrivelsen af V2 sprog generelt. 
I dansk stiller sagen sig imidlertid anderledes. Det er min hovedpåstand at dansk i sit kommunikative repertoire har en særlig strukturel kategori af sætningslignende udtryk hvis væsentligste funktion er blot at satte et topic. Til denne option er knyttet et træk der i sine manifeste former ofte klandres af purister ('dobbelt relativ', 'som at', etc.). Der vil iflg. denne opfattelse være mening $\mathrm{i}$ at skelne $\mathrm{CP}$ fra TopP som to strukturelt forskellige kommunikative udtryksformer, hvor CP kategoriserer prædikationer mens TopP kategoriserer eksklamationer. For de centrale af dem, nemlig sikke-udtryk, er der tale om de fornævnte 'feature placing statements', som Strawson havde en sprogfilosofs intuitive forståelse for måtte 'være der', men som ikke indgår som særlig konstruktionsmulighed i det sprog han forholdt sig til, og som han derfor måtte illustrere temmelig upræcist med ekspletive konstruktioner som there is gold here.

Dette betyder at man for en udtømmende beskrivelse af dansk, i modsætning til engelsk, behøver en syntaktisk topknude, TopP, og at (45)(b) således kræves til beskrivelse af en række danske udtryk. Centralt blandt disse er udtryk indledt med sikke, men der er også andre, bl. a. indledt med gid. De foreslåede strukturer for sikke-udtryk er (47)(a), for gidudtryk (47)(b) og for udtryk med mon (47)(c):

(47) a.

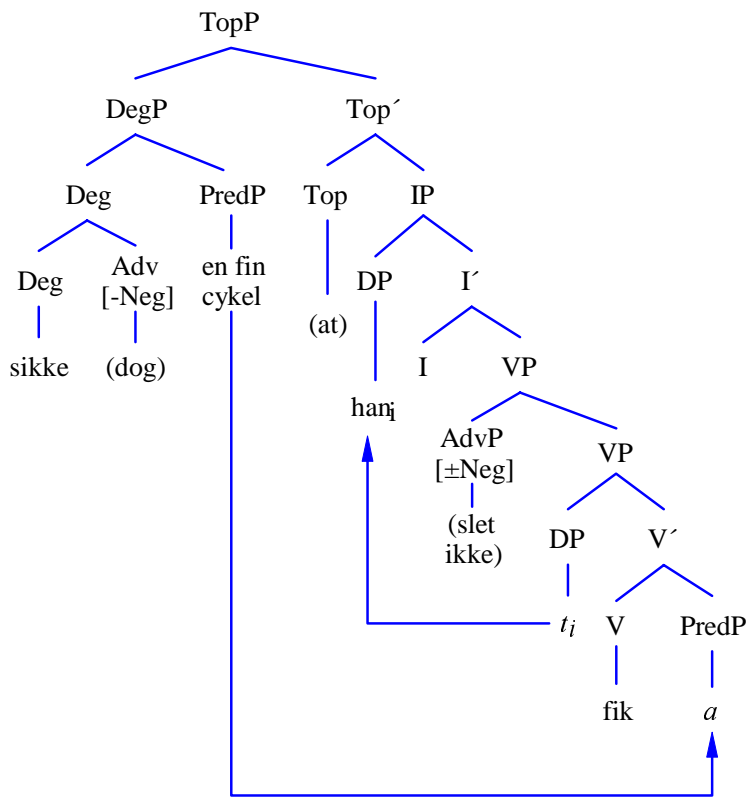


(47) b.

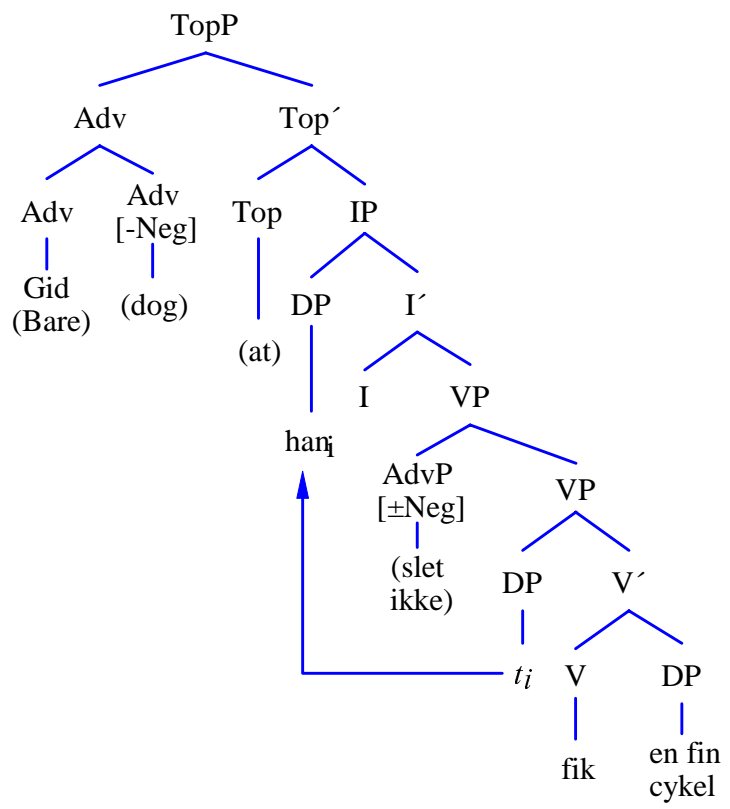

(47) c.

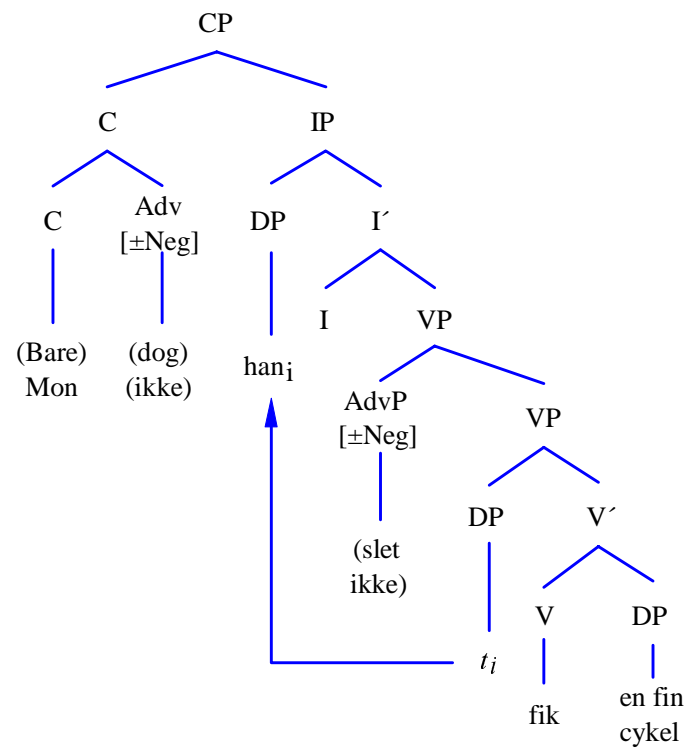


Der er her introduceret en Top(ic) P(hrase), i modsætning til en CP. Udtryk med sikke og gid er undtagelsesløst ${ }^{14}$ TopP, med mon undtagelsesløst CP. Udtryk med bare kan være begge. TopP adskiller sig strukturelt fra $\mathrm{CP}$ ved som kerne at have en medial konjunktionsagtig partike ${ }^{15}$, der i rigsdansk normalt er uudtrykt efter sikke ${ }^{16}$, men som i standard skriftsprog undertiden markeres med komma. Desuden forekommer den dialektalt (i hvert fald i vestsjællandsk), enten i form af at eller (sjældnere) som (at). XP-udtrykket udgør, i form af en Deg(ree) P(hrase), [Spec,TopP] med sikke som kerne. Bare og gid, derimod, er blot adverbielle kerner der tilsyneladende hverken kan specificeres eller komplementeres. Højreadjungeret til kernen kan der være et medlem af en meget begrænset klasse af adverbier, der funktionelt-semantisk modaliserer talers holdning til indholdet af komplementet på forskellig vis, bortset fra negation. Det ville være i modstrid med såvel det 'eksistentielt sættende' indhold af sikke som det 'optativt sættende' indhold af bare og gid.

Der er to forhold nedfældet i (47)(a) som jeg vil diskutere nærmere: Påstanden om en Pred(icative) P(hrase) som komplement (se 3.2.1. nedenfor) og langdistanceforholdet imellem den øvre og nedre PredP, angivet med $a$ (for associeret), der på afgørende vis udfordrer det generative grundprincip om flytning (3.3.1. nedenfor).

\subsubsection{Pradikative fraser (PredP)}

Lad os definere en prædikativ frase som den maksimale projektion af en leksikalsk metakategori med trækspecifikationen $[+\mathrm{N}]$ (dvs en 'superkategori' hvis medlemmer er leksemer der grammatisk realiseres som de

\footnotetext{
14 Under indtryk af forholdene illustreret i (37)-(38) kunne man argumentere at $S$-udtryk med sikke som selvstændigt adverbium genereres efter (47)(c). Dette ville samtidig betyde at udtryk som Sikke at folk dog opfører sig tåbeligt måtte betragtes som ugrammatiske. Hvis de derimod akcepteres, evt. som substandard, foreligger der imidlertid også en anden — og efter mit skøn bedre — mulighed som vil blive omtalt i afsnit 3.5.

15 Der er til dels tale om det fænomen der i den danske grammatiske tradition går under betegnelsen 'det pleonastiske $a t^{\prime}$ ' (Hansen, 1983), men realisationen af Top ${ }^{\circ}$ er ikke begrænset til at alene. Yderligere realisationsmuligheder diskuteres nedenfor.

16 Der er et enkelt belagt eksempel med gid, at i Bergenholtz 87/90: ${ }^{\circ}$ Gid, at jeg må blive lige så heldig, når jeg og Allan får et barn sammen. Udtryk med bare at er noget hyppigere i standard talesprog: Bare at han nu ikke kommer galt afsted. Hansen (1983:72) giver desuden et par autentiske eksempler med sikke- + at.
} 
leksikalske kategorier $\mathrm{N}(=[+\mathrm{N},-\mathrm{V}])$ og $\mathrm{A}(=[+\mathrm{N},+\mathrm{V}]))$, og som samtidig har den distributionelle egenskab at kunne fungere som subjektsprædikat $\left(\mathrm{P}_{\mathrm{S}}\right)$. På denne måde får vi inddelt klassen af DP'er i to: stcerke, som nok har trækspecifikationen $[+\mathrm{N}]$, men som ikke kan optræde prædikativt, og svage. Denne inddeling går tilbage til Milsark (1977) og afhænger af hvilken type determinativ de indledes med. En stærk DP (herefter SDP) har i medfør heraf yderligere trækspecifikationen $[+\mathrm{EP}]$ mens en svag (PDP) har [-EP] (se afsnit 2.1. ovenfor). Der er forskellige måder man kan introducere denne skelnen i strukturelle beskrivelser. F. eks. foreslår Zamparelli (1996) en lagdelt beskrivelsesform hvori SDP tager PDP som komplement ${ }^{17}$. Jeg vil imidlertid her benytte en lidt anden strategi, baseret på introduktionen af de nævnte trækspecifikationer på relevante NP knuder, primært med den begrundelse at der synes at være en høj grad af strukturelt sammenfald imellem de forskellige undertyper af NP der opstår på denne måde. Dette kan relativt nemt relateres til aktiveringen af forskellige trækspecifikationer på de samme strukturelle pladser hvor Zamporelli må operere med forskellige strukturbeskrivelser. Det giver følgende billede:

$$
\begin{array}{lll}
\text { a. } & {[+\mathrm{N},-\mathrm{V},+\mathrm{EP}]} & =\mathrm{SDP} \\
\text { b. }[+\mathrm{N},-\mathrm{V},-\mathrm{EP}] & =\mathrm{PDP}(\in \mathrm{PredP}) \\
\text { c. } & \{\mathrm{SDP}, \mathrm{PDP}\} & \in \mathrm{DP}
\end{array}
$$

Den anden undertype af PredP er AP. Det kan umiddelbart forekomme overflødigt at operere med en PredP under vanlige forestillinger om at AP er konstituent i DP. Kunne man ikke blot operere med de to DPvarianter i (48), som hver især i deres interne konstitution rummer AP? Det kan man muligvis godt — men i så fald skal man finde en forklaring på et specielt træk ved AP under sikke. Det er velkendt at adjektiver kan optræde som selvstændig kerne i danske nominaler, i modsætning til engelsk:

$$
\begin{aligned}
& \text { a. han tog den store (= he took the big one) } \\
& \text { b. vi har ikke flere af de grønne (= we don't have any more left of the } \\
& \text { green ones) }
\end{aligned}
$$

Denne syntaktiske egenskab ser det ud til danske adjektiver taber når de indgår i sikke-udtryk:

\footnotetext{
17 Der er to yderligere lag: KIP (for "KindPhrase") er komplement til PDP og tager selv NP som komplement.
} 
(50) a. ${ }^{\circ}$ sikke en dejlig fyldig en du har

b. *sikke en dejlig fyldig du har

I tilfælde hvor et adjektiv alene er komplement til sikke kan det kun være uden artikel:

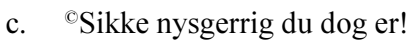

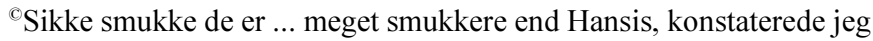

Der er således en strukturel forskel imellem AP og PDP i denne funktion, en forskel der plausibelt kan henføres til sikke's kategoriselektion. Vælges PDP skal der være en (pro)nominal kerne for evt. attributive adjektiver (se 3.5. for en mere udførlig diskussion heraf), vælges AP skal kernen derimod være et selvstændigt adjektiv. Det fremgår af numeruskongruensen $\mathrm{i}(50)(\mathrm{c})$ at den situation opstår når $\mathrm{AP}$ fungerer som $\mathrm{P}_{\mathrm{S}}$. Der vil altså ligeledes i normal prædikativ position skulle skelnes imellem AP og PDP. Det følger at den konkrete struktur (47)(a) er upræcis i den forstand at PredP skal erstattes med PDP.

Der er imidertid en begrænsning på AP under sikke — men ikke under gid og bare - $\mathrm{i}$ forhold til AP som $\mathrm{P}_{\mathrm{S}}$ :

a. Græsset på den anden side af gærdet er altid grønnere/grønnest

b. *Sikke grønnere/grønnest græsset på den anden side af gærdet altid er

Det gælder som allerede nævnt at komparativer og superlativer ikke kan komplementere sikke. Den implicite sammenligning der er knyttet til deres semantik er ikke forenelig med [+EP], der indgår i sikke's semantiske specifikation. Denne begrænsning lader sig simplest forklare hvis man går ud fra at der netop ikke er tale om en flytning af $\mathrm{P}_{\mathrm{s}}$ til komplementpositionen under sikke, men derimod om en association imellem de to positioner [Deg',Compl] og [V',Compl]. Nærmere argumentation for det forudsætter imidlertid en opsummering af $X P$-udtryks syntaktiske funktioner.

\section{3. $X P$-udtryks syntaktiske funktioner}

Denne overskrift er nu upræcis. ' $X P$-udtryk' var den præanalytiske, intuitive betegnelse for sikke-udtryk, både når de optrådte som selvstændige ytringer og når de formodedes at indgå som konstituenter i $S$-udtryk. En af konklusionerne på den hidtige diskussion har imidlertid været at XPudtryk som konstituenter betragtet er DegP'er med kun én funktion, nem- 
lig som [Spec,TopP]. Derimod har den associerede til $X P$-udtryk syntaktiske funktioner i den (prædikative) side af en struktur som (47)(a).

Det viser sig at der er en ganske overvældende majoritet af eksempler hvor associationsrelationen holder imellem [ $\left[\mathrm{Deg}^{\prime}, \mathrm{Compl}\right]$ og [ [V',Compl], nemlig alle de tilfælde hvor sikke's komplement tolkes som enten $\mathrm{O}, \mathrm{O}_{\mathrm{P}}$ $\mathrm{i}$ forbindelse med et præpositionelt verbum, eller $\mathrm{P}_{\mathrm{S}}$, som i:

(52) a. "Sikke en fart, du har på i dag", sagde mor forbløffet (ialt 36 eksempler)

b. $\quad$ Men sikke da noget bræk at komme med (ialt 2 eksempler)

c. 'Sikke nysgerrig du dog er! (ialt 2 eksempler)

$\mathrm{Da}$ alle tre typer leverer skyts til argumenterne for association tages de op igen i afsnit 3.3.1. Dette efterlader to klasser af udtryk, nemlig dels dem hvor den associerede tolkes som subjekt for $\mathrm{V}$, dels dem hvor den tolkes som (en del af et præpositionelt) adjunkt (adverbialt):
a. ${ }^{\circ}$ Hold kæft gutter, sikke en rapand, der kommer vraltende (ialt 7 eksempler)
b. $\quad$ Sikke de unge nu kan få foretaget abort (ialt 4 eksempler)
c. ${ }^{\circ}$ Men sikke obsternasig hun havde opført sig (ialt 2 eksempler)
d. $\quad$ sikke en måde at starte sin sommerferie på (ialt 4 eksempler)

I (a) fremhæves (indholds)subjektet. De udviser samtidig nær affinitet til ekspletive udtryk og vil blive diskuteret i den sammenhæng i afsnit 3.4. I (b) er der ikke noget komplement til sikke. I særdeleshed bemærkes det at sikke ikke fremhæver subjektet (de unge), men tværtimod hele sætningen. Dette er det klassiske eksempel på sikke's adverbielle funktion. I (c) er der tale om association til et adjungeret VP-mådesadverbial og i (d) om association til styrelsen i en præpositionsforbindelse med samme funktion. Begge typer leverer empirisk støtte til argumenterne for association snarere end flytning, så de bliver også taget op igen.

Der er to syntaktiske funktioner der ikke i datamaterialet er realiseret af $X P$-udtrykkets komplement, indirekte objekt og objektskomplement. Der er blot en enkelt forekomst af et indirekte objekt (bortset fra 'etisk dativ' i 2 eksempler) og det er ikke komplement til sikke. Med en enkelt modifikation - for at ophæve den generiske semantik af voksne mennesker - kan det imidlertid sagtens være det:

(54) a. 'Sikken en gang tidrøvende nonsens benzinstationerne byder voksne mennesker 
b. Sikke mange voksne mennesker benzinstationerne byder en gang tidrøvende nonsens.

Objektskomplementet er tilsyneladende udelukket som komplement til sikke som PDP (a), men ikke som AP (b):

a. *Sikke en mandschauvinist hun kaldte ham

b. Sikke træt hun havde redet hesten

Der er således fire designerede positioner hvormed sikke umiddelbart kan associere sit komplement i et $X P$-udtryk: Komplementer til $\mathrm{V}^{18}$ og et VP-adjungeret mådesadverbial. Dertil kommer subjektspositionen, som det danner en associationskæde med, til [Spec, VP] via [Spec,IP]. Disse er alle semantisk selekteret af V. Den generelle struktur ser således ud:

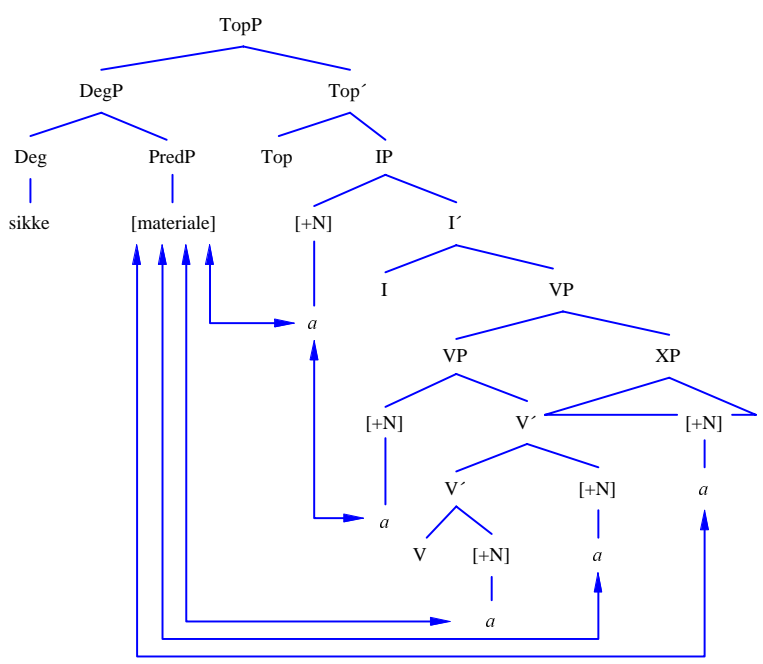

18 Analysen af dobbelt objekt konstruktioner har altid voldt vanskeligheder i generativ grammatik (for diskussioner af aktuelle positioner se Herslund 1986; Larson 1988,1990; Johnson 1991; Bowers 1993). Jeg har her valgt den i mine øjne simpleste tese forenelig med bijektionsprincippet, at ditransitive og kompleks transitive verber projicerer en rekursiv bjælkestruktur således at den 'inderste' $V$ ' dominerer hhv. det direkte og det indirekte objekt når den 'yderste' dominerer hhv. objektskomplement og direkte objekt. Det kan der formentlig rejses både teoretiske og empiriske indvendinger imod. F. eks. gives der nu ingen strukturel grund til at PDP-objektskomplementer ikke kan være associerede for sikke-komplementer. Men den præcise udformning spiller ikke den store rolle her, for den ville under alle omstændigheder være tvunget til at basisgenerere det indirekte objekt $\mathrm{i}$ en position hvori det kan tilskrives en theta-rolle af V, dvs. i VP's domæne. Det er det der er det afgørende. 
Der vil nedenfor blive argumenteret for to skarpt adskilte, men associationsrelaterede dele af denne struktur. Vi vil derfor omtale [Spec,TopP] som 'specifikatorstrengen', [Top', Compl] som 'komplementstrengen'.

\subsubsection{Association kontra flytning}

Generelt repræsenterer strukturen (56) et alternativ til flytning. Chomsky (1994:253f) identificerer tre basale egenskaber ved kæder formet ved flytning: de skal overholde c-command klausulen, hvorefter en flyttet konstituent skal c-kommandere sit spor, de skal overholde klausulen om uniformitet, hvorefter en flyttet konstituent skal have samme frasestrukturelle egenskaber som sit spor, og de skal overholde det økonomiske princip om 'Last Resort', hvorefter flytning kun kan forekomme hvis der er en grund til det, specifikt at 'feature checking' ikke vil kunne finde sted uden.

Strukturen (56) bryder mindst to af disse klausuler, c-command og uniformitetsklausulen. C-command klausulen ville diskvalificere (56) fordi den som helt generel konsekvens har at konstituenter ikke kan flytte til komplementpositioner. Uniformitetsklausulen ville diskvalificere den, for — som det vil fremgå — der er ikke nødvendigvis streng identitet imellem sikke's komplement og dets associerede. Enten er sikke ikke en kerne og tager derfor ikke et komplement der lader sig tolke som objekt (etc.) for $\mathrm{V}$, eller også må der være en alternativ proces til flytning der kan garantere informationsdeling imellem to knuder i en sætningsstruktur.

Det blev påvist i afsnit 3. at $X P$-udtryk der tolkes som objekt af flere grunde ikke kan være basisgenereret i [ $\left.\mathrm{V}^{\prime}, \mathrm{Compl}\right]$ og dernæst flyttet til [Spec,CP] ved operator-flytning. En af dem var at sikke ikke lader sig opfatte som en særlig slags HV-operator fordi den ikke kan efterlades in situ i ekko-spørgsmål. Den eneste anden mulighed er at sikke er en leksikalsk størrelse, og da leksikalske størrelser normalt antages at være terminalelementer og dermed kerner (sml. Chomsky 1994:245), følger det at vi må antage eksistensen af en informationsdelende proces som alternativ til flytning. Dette er et relativt vidtgående skridt og må derfor bakkes op empirisk.

Indledningsvis kan der imidlertid rejses et teoretisk punkt. Associeret med flytning er princippet om at den flyttede konstituent efterlader sig et spor ('trace') i basispositionen, ko-indekseret med såvel den deriverede position som de positioner den måtte være landet $\mathrm{i}$ undervejs (på grund 
af forskellige principper om 'lokale' operationer). Samtidig sikrer ccommand klausulen at der kun kan flyttes 'opad' i en struktur. Det indeks der skal holde styr på en konstituents vandring op igennem en struktur var oprindeligt tænkt som et referentielt indeks, et indeks der skulle anskueliggøre at antecedenter og forskellige pronominale former var koreferente. Rizzi (1990:86) formulerer en klausul — som vi her vil følge - til sikring af at kun argumenter (dvs refererende nominaler) tildeles et referentielt indeks:

(57) A referential index must be licensed by a referential theta role.

Men PDP'er ikke refererende nominaler. Derfor er i (56) [<materiale $>$ ] ikke indekseret og altså ikke ko-indekseret med $a$, der heller ikke er et spor. Det er derimod en associeret, en term der i øvrigt bruges om indholdssubjektet i sætninger med ekspletivt subjekt (ES), som

(58) $\left[_{\mathrm{ES}}\right.$ Der $]$ er $\left[_{\mathrm{a}}\right.$ en flue] i min suppe

De vil blive udførligt diskuteret i afsnit 3.4. Indtil da vil jeg mønstre de forhåndenværende empiriske argumenter for påstanden om at associationsrelationen, snarere end flytning, udgør basis for analysen af sikkeudtryk. Betragt først eksemplerne under (52), gentaget her:

(59) a. "Sikke en fart, du har på i dag", sagde mor forbløffet

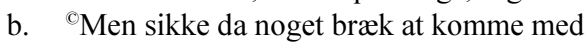

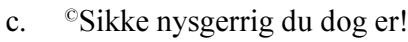

'At have fart på' i (59)(a) er en inkorporerende konstruktion; smlg. derfor: (60) i. a.
b.
*Han havde en fart på

Han havde fart på

ii. a.

* Sikke fart han havde på

b. Sikken fart han havde på

c. Sikke en fart han havde på

Hvis der var tale om flytning skulle man forklare hvorfor (ii) kræver tilstedeværelse af den ubestemte artikel som ikke er mulig i den (inkorporerede) objektsposition under (i). En sådan forklaring ville blive ad $h o c$, med mindre der kan gives uafhængige grunde til at kun en del af den trækspecifikation der udgør en knude skulle flytte. Under antagelsen om association, derimod, kan man forsvare det synspunkt at to knuder kan associeres på basis af en fælles delmængde af træk, f. eks. [+N,-V]. 
De to eksempler (59)(b) og (c) bidrager med ens type argument. I konstruktioner genereret over den samme relevante numeration af leksikalier uden sikke ville vi få flg.:

(61) a. *Han kommer da med noget bræk > han kommer da med noget $\{$ verre $\mid$ forbandet $\mid$ etc. $\}$ bræk

b. 'du er dog nysgerrig! > du er vel nok nysgerrig!

'At komme med noget $\{A\}$ braek' er et semi-idiomatisk udtryk hvor adjektivet er variabelt inden for ret snævre grænser der har med graduering at gøre. Men det kan ikke udelades. Dette kunne naturligvis tjene som argument for at sikke er et adjektiv med særlige syntaktiske egenskaber, bl. a. evnen til at 'absorbere' et obligatorisk attributivt adjektiv når det som konstituent $i$ en DP(?) flyttes ind under dets skopus. Omvendt kan det imidlertid også tjene som argument for at sikke har skopus over en attributiv A-projektion i PDP, og at denne PDP blot har association til en knude med trækspecifikation $[+\mathrm{N},-\mathrm{V}]$ under $\mathrm{P}($ med $)$. Herom senere.

I (59)(c) er det eksplicit forekomsten af $d o g$ som adverbium der tæller som argument. Det er flere gange fremhævet at $\operatorname{dog}$ (sammen med ganske få andre) kan optræde i tilknytning til sikke uden prosodisk brud. Vel nok er ikke et af dem:
a. *Sikke vel nok nysgerrig du er
b. Sikke nysgerrig du vel nok er

Omvendt vil vel nok være det naturlige valg af adverbium i forbindelse med en ligefremt fremsættende sætning som (61)(b). En sådan leksikalsk variation er naturligvis ikke noget argument i sig selv for eller imod flytning, med mindre det kombineres med en hypotese om den mentale processering involveret i sætningsgenerering $i$ det hele taget. Under aktuelle minimalistiske antagelser er dette imidlertid så vidt jeg kan se netop hvad der lægges op til (se Chomsky 1995:189). Hvis fri leksikalsk selektion løbende begrænses af (det der kaldes) 'phonological spell-out', implicerer forhold som de her nævnte en processuel linearitet hvor selektion af sikke i en eller anden forstand må være primær i forhold til selektion af adverbium. Men en sådan selektionslinearitet forekommer at modsige selve princippet om flytning.

Betragt dernæst de relevante eksempler under (53), gentaget her:

\footnotetext{
c. ${ }^{\circ}$ Men sikke obsternasig hun havde opført sig

d. sikke en måde at starte sin sommerferie på
} 
'At opføre sig $\{A d v\}$ ' er igen et semi-idiom. Når det optræder i ligefremt fremsættende sætninger er det da også altid morfologisk markeret som adverbium:

(64) han opførte sig vel nok \{pæn $t|\operatorname{god} t| \operatorname{dårlig} t \mid$ obsternasig $t \mid$ etc. \}

Hvis der var tale om at obsternasig var flyttet op under sikke i (63)(c) ville det kræve en forklaring at denne adverbiumsmarkering var gået tabt undervejs. Under påstand om association, derimod, ville man kunne påberåbe sig en fælles delmængde af træk imellem adjektiv og adverbium som basis for relationen.

I (63)(d) er der tale om samme type argument som det der knytter sig til (59)(b). Uden sikke-konstruktion ville vi vente at finde (65)(a) mens (b) er udelukket:

(65) a. han startede sin sommerferie på en \{forvirret | irriterende | god | dejlig | etc.\} måde

b. *han startede sin sommerferie på en måde

Også her måtte man ty til 'absorberingsargumentet' (el. lign.) for at forklare en flytning der ikke ville omfatte et attributivt adjektiv der var nødvendigt i udgangspositionen.

Den sidste type evidens for association vedrører for så vidt ikke direkte (det jeg her har kaldt) den associerede. Der er to argumenter af denne type. Det første vedrører den flere gange omtalte morfologiske variation imellem de tre former sikke, sikken og sikket. Der er, vil jeg hævde, tale om et kontraktionsfænomen.

Bemærk at hverken sikken eller sikket optræder i datamaterialet $\mathrm{i}$ tilfælde hvor $\operatorname{dog}$ (eller andre adverbier) optræder umiddelbart efter sikke. Dette forhold giver mindelser om begrænsningerne på engelsk AUXkontraktion, som illustreret i:

(66) a. he's a nice guy

b. *he sure's a nice guy

Når et adverbium optræder imellem sikke og en følgende ubestemt artikel kan sikke ikke kontrahere med artiklen. ${ }^{19}$ Men her standser ligheden også. Hvis der altid blot var tale om artikelkontraktion skulle vi ikke vente at

19 At [sikken] syntaktisk optræder som kontraktion af [sikke+en] fremgår af eksemplerne i (60). 
finde [sikken en], og langt mindre [sikken et], vel at mærke hvis man som udgangspunkt har at kontraktion er en (kerne)flytningsoperation (se Radford 1997:330ff, der ganske vist er begrænset til AUXkontraktion). Og det ville ikke kunne forklare registrerede konstruktioner som [sikken nogen/noget/nogle]. Derimod ville man fortsat - under antagelsen om fælles delmængder af træk som den legitimerende basis - argumentere for at associationsrelationen holder, ikke blot imellem sikke's komplement og (designerede positioner i) V's komplement, men også imellem sikke selv (som kerne) og dets komplements determinativposition. Man ville kort sagt kunne generalisere associationsrelationen til andre strukturelle konfigurationer.

Det andet argument er tveægget i den forstand at det ikke specielt taler til fordel for association, men blot viser at der er kvalitative hensyn at tage ved fastlæggelsen af betingelser for flytning/ association. Det vedrører den tværsproglige typologiske distribution af præpositionsstranding. I en omhyggelig gennemgang af disse fænomener i de germanske sprog fremsætter Herslund (1984) den tese at præpositionsstranding, der stort set er ubegrænset i de skandinaviske sprog, ikke forekommer i tysk fordi præpositioner dér tilskriver deres komplement inherent og morfologisk kasus. Han illustrerer situationen med følgende paradigme, som han citerer efter van Riemsdijk (1978:167):

(67) (= Herslunds (58))
a. Den Hans, den mag ich nicht
b. *Den Hans, an den erinnere ich mich nicht
c. Der Hans, an den erinnere ich mich nicht

Herslunds kommentar:

Under left dislocation there is case attraction from the object of a verb, (58) a., but no attraction from the object of a preposition, (58) b.; instead, you have the unmarked nominative case. So, if stranding took place, prepositions would have to assign case at a distance, which they seem unable to do. Accordingly, the only way a preposition can assign case to its object is to keep the PP intact, and that rules out the possibility of stranding:

(68) (= Herslunds (59))
a. An wen erinnerst du dich?

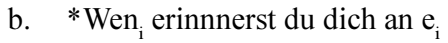


Der kan imidlertid, som Herslund selv påpeger, ikke være tale om et universelt forbud mod P-stranding i morfologiske kasussprog, for begge fænomener forekommer i islandsk. Det kan tilføjes at det også forekommer i dansk i de få tilfælde hvor der er morfologisk kasusvariation:
a. ([Ham Hans $]_{i}$ ) ham tænkte jeg ikke på $\mathrm{e}_{\mathrm{i}}$
b. *På ham tænkte jeg ikke

Den observerede forskel imellem dansk og tysk på dette punkt skal derfor henføres til de to sprogs betingelser for flytning. Blandt dem kunne være parametriserede forskelle i forholdet imellem udnyttelse af association og udnyttelsen af flytning, muligvis - som foreslået af Herslund - i form af implikative generaliseringer fra kasustilskrivning.

I tilgift til disse empirisk funderede argumenter er der et metodisk/ teoretisk. I minimalistisk teori opereres med to typer flytning, åbenbar ('overt') og skjult ('covert'). De er associeret med hhv. det fonologiske og det logiske interface, således at åbenbar flytning er fonologisk synlig mens skjult flytning udelukkende formodes at foregå i den logiske form og altså ikke efterlade sig synlige spor i den fonologiske struktur.

En påstand om flytning hvis resultat ikke kan ses/høres kræver solid empirisk rygdækning for at virke overbevisende. Imidlertid forekommer det empiriske grundlag der bringes til torvs som forklaring på f. eks. de forskelle der gør sig gældende i diverse (germanske) sprogs $\mathrm{V}^{\circ}$-til- $\mathrm{I}^{\circ}$ flytning og dermed sammenhængende ekspletivkonstruktioner, ikke specielt solidt. Der henvises til et skel imellem såkaldt stærke og svage grammatiske træk på basis af disse træks fleksionsmorfologiske manifestationsformer (Chomsky 1995:232ff; 340ff). Stærke træk medfører åbenbar flytning, svage træk derimod skjult. Dermed er bevisbyrden lagt på en plausibel redegørelse for hvad der gør træk stærke hhv. svage, og på det punkt hersker der nogen usikkerhed (se Vikner 1995:132ff et passim for en grundig diskussion; også Sigurðsson 1996; Lasnik 1999).

Chomskys (1995:316f) henvisning til den generative tradition for flytning virker i denne forbindelse lidet overbevisende. Han har naturligvis ganske ret $\mathrm{i}$ at "[t]here is no meaningful controversy over the basic facts" når der hermed blot sigtes til det empiriske faktum "that items commonly appear 'displaced' from the position in which the interpretation they receive is otherwise represented at the L(ogical) F(orm) interface." Problemet med skjult flytning er imidlertid at de konstituenter, der formodes ramt af den, netop ikke optræder 'displaced'. 
Hvor flytning i tidligere versioner af teorien var en rent deskriptiv foranstaltning tillægges der nu den menneskelige sprogevne — opfattet som en beregningsmaskine ('computational device') — egenskaber der beskrives ved termer som 'åbenbar' og 'skjult flytning'. Det turde i bedste fald blot være metaforiske udsagn om processer der fortsat blot kan gisnes om. I så fald vil der næppe være den store empiriske forskel imellem denotationen af et metaforisk udtryk som 'skjult flyttet konstituent' og denotationen af et ligeledes metaforisk udtryk som 'associeret'. ${ }^{20}$ Derudover er det naturligvis fortsat et empirisk spørgsmål at gøre rede for de begrænsninger der gælder for fænomenet, uanset navn.

\subsection{Sikke og ekspletive konstruktioner}

Ekspletive konstruktioner har altid været genstand for stor opmærksomhed i generativ analyse (se Vikner 1995:kap. 6-7). De er relevante for vort projekt her $i$ den forstand at de udgør det prcedikative (CP) modstykke til S-udtryk (TopP). ${ }^{21}$ Og et af de mere interessante aspekter af den sammenhæng er at de to kombineres i dansk under klart definerbare omstændigheder.

Det bemærkelsesværdige ved eksempler under (53)(a) — gentaget her som (70)(a) - er at de tilsyneladende alle kombinererer sikke med en ekspletiv konstruktion. Smlg. følgende:

(70) a. ${ }^{\circ}$ (Hold kæft gutter,) sikke en rapand, der kommer vraltende

b. Der kommer en rapand vraltende

c. *Sikke en rapand kommer vraltende

Det er som bekendt ikke alle verbaltyper der kan indgå i en ekspletiv konstruktion i dansk:

(71) a. Der $\{$ hang $\mid$ gik $|\operatorname{kom}|$ lå $\mid$ løb $\mid$ sad $\mid$ etc.\} en dreng ude i haven

b. *Der \{grinede $\mid$ græd $\mid$ lo $\mid$ råbte $\mid$ sang $\mid$ etc. $\}$ en dreng ude i haven

${ }^{20}$ Herslund (1984:51) når til samme konklusion i sin diskussion af præpositionsstrandingsfænomener:

Referring to these structures as results of movement operations is simply a shorthand way of saying that the complement of the PP is separated from the PP in the surface structure. Either way, this discussion is hardly vital for the description, and I will not pursue it further here.

${ }^{21}$ Se dog afsnit 3.5.2. for en sandsynlig undtagelse fra denne generelle regel. 
c. Der blev \{grinet $\mid$ grædt $\mid$ leet $\mid$ råbt $\mid$ rodet $\mid$ sunget $\mid$ etc. $\}$ ude i haven

d. *Der \{bed $\mid$ kyssede $\mid$ slog $\mid$ sparkede $\mid$ etc. $\}$ en dreng en pige ude i haven

e. *Der blev \{bidt | kysset $\mid$ slået | sparket | etc. $\}$ en pige ude i haven

f. Der blev \{bidt $\mid$ kysset $\mid$ slået $\mid$ sparket | etc. $\}$ ude i haven

g. $\quad *$ Der $\{$ brækkede $\mid$ knækkede $\mid$ smadrede $\mid$ væltede $\mid$ etc. $\}$ en vind et træ ude i haven

h. Der \{brækkede $\mid$ knækkede $\mid$ smadrede $\mid$ væltede $\mid$ etc. $\}$ et træ ude i haven

i. Der var/blev \{brækket | knækket | smadret | væltet | etc. $\}$ et træ ude i haven

j. $\quad$ Der $\{$ blev | var | opstod | udviklede sig | viste sig | etc. $\}$ et problem ude i haven

Vikner (1995) videreudvikler en version af den klassiske generative beskrivelse af ekspletive udtryk der som nøglepunkt har at ekspletivet via en 'kæde' ('chain') er associeret med et argumentativt NP der ville være subjekt hvis ekspletivet ikke var der. Han forklarer nogle af de syntaktiske forskelle under (71) med henvisning til forskellige underkategoriseringer af verber (Vikner, 1995:196f; 202 ff). F. eks. tilskrives - i medfør af den såkaldte 'Burzios generalisering' (Burzio 1986:178ff) - forskellen imellem de to grupper af intransitive verber i (a) og (b) den omstændighed at (a) i modsætning til (b) indeholder ergative verber hvis særkende er at de kun tilskriver én theta-rolle — og ingen strukturel kasus — til deres interne argument (dvs i [V', Compl]), idet de slet ikke har noget eksternt (dvs i [Spec, VP]). Vikner diskuterer ikke transitive verber af typen eksemplificeret $\mathrm{i}(\mathrm{g})$-(i), verber der $\mathrm{i}$ en anden teoretisk tradition end Vikners kategoriseres som ergative-kausative (Anderson 1971;1977;1997), i modsætning til dem eksemplificeret i (d)(f) der hos Vikner er transitive, hos Anderson blot ergative. M.h.t. verber eksemplificeret under (j) henviser Vikner (1995:197) til Milsarks distinktion imellem 'indre' og 'ydre' verbaler således at verberne i (j) alle er eksempler på verber der tager et internt argument (bortset fra vare og blive, der som 'intensive' verber naturligvis ikke har et argument). Vurderet ud fra eksemplerne under (71) er der under Vikners antagelser tydeligvis kun mulighed for en ekspletiv konstruktion hvis verbet enten er uden interne argumenter ((c), (f), (i), (j)), eller hvis dets interne argument er associeret med ekspletivet ((a), (h)).

Hvis vi nu - med udgangspunkt i (70)(b) — danner $S$-udtryk over (71) efter mønstret i (70)(a) viser det sig imidlertid at samtlige er fuldt 
akceptable og grammatiske (dem vi ikke skulle forvente - fordi de er ugrammatiske i (71) - er markeret med "'):

(72) a. Sikke en dreng der $\{$ hang $\mid$ gik $\mid$ kom $\mid$ lå $\mid$ løb $\mid$ sad $\mid$ etc. $\}$ ude i haven

b. 'Sikke en dreng der \{grinede $\mid$ græd $\mid$ lo $\mid$ råbte $\mid$ sang $\mid$ etc. $\}$ ude i haven

c. Sikke der blev \{grinet $\mid$ grædt $\mid$ leet $\mid$ råbt $\mid$ rodet $\mid$ sunget $\mid$ etc. $\}$ ude i haven

d. 'Sikke en dreng der \{bed $\mid$ kyssede $\mid$ slog $\mid$ sparkede $\mid$ etc. $\}$ en pige ude i haven

e. 'Sikke en pige der blev $\{$ bidt $\mid$ kysset $\mid$ slået $\mid$ sparket $\mid$ etc. $\}$ ude i haven

f. Sikke der blev \{bidt | kysset | slået | sparket | etc. $\}$ ude i haven

g. 'Sikke en vind der $\{$ brækkede $\mid$ knækkede $\mid$ smadrede $\mid$ væltede $\mid$ etc. $\}$ et træ ude i haven

h. $\quad$ Sikke et træ der $\{$ brækkede $\mid$ knækkede $\mid$ smadrede $\mid$ væltede $\mid$ etc. $\}$ ude i haven

i. Sikke et træ der var/blev $\{$ brækket $\mid$ knækket $\mid$ smadret $\mid$ væltet $\mid$ etc. $\}$ ude i haven

j. $\quad$ Sikke et problem der $\{$ blev $\mid$ var $\mid$ opstod $\mid$ udviklede sig $\mid$ viste sig $\mid$ etc. $\}$ ude i haven

Hvis vi hævder at alle eksemplerne i (72) er en kombination af sikke og en normal ekspletiv konstruktion kan det således ikke være verbalkategoriseringen der er afgørende for ekspletivkonstruktioner. Det ville være en uvelkommen konklusion, i modstrid med overvældende empirisk evidens. Lad os derfor lede efter alternative forklaringer.

\subsubsection{Alternativer}

Den uvelkomne konklusion er nået på basis af to præmisser: 1) at der i alle tilfælde i (72) er et ekspletiv og derfor står i [Spec,IP] i komplementstrengen; 2) at den associerede til ekspletivet er et argumentativt NP. Lad os se nærmere på hver af disse præmisser.

Indledningsvis udnytter vi den særlige egenskab ved $X P$-udtryk at de kan tælle som selvstændige ytringer og sidestilles med helsætninger. En sådan opløsning af eksemplerne i (72) resulterer i to semantisk baserede grupperinger (idet vi indskrænker os til et enkelt repræsentativt verbum):

(73) b. Sikke en dreng. Han grinede ude i haven.

d. Sikke en dreng. Han bed en pige ude i haven.

e. Sikke en pige. Hun blev kysset ude i haven.

g. Sikke en vind. Den knækkede et træ ude i haven. 
Her fremhæver følgesætningen et situeret træk som det der i talerens forståelse af denotationsbetingelserne for prædikaterne 'dreng', 'pige' og 'vind' i denne kontekst sanktionerer en implicit vurdering af referenten som 'noget særligt'. Vurderingen er baseret på akcept af den følgende proposition som sand. Dette er den naturlige tolkning af (73), og dermed af de tilsvarende eksempler under (72). Lad os omtale sådanne eksplicite propositioner som begrundelsesscetninger, uanset hvilken form de måtte have. En tilsvarende tolkning af (74) — og dermed (72) (a, h, i, j) — er mulig, men ikke i noget tilfælde specielt naturlig, fordi følgesætningerne her ikke fremhæver et træk blandt prædikaternes denotationsbetingelser der normalt kan sanktionere en gradueret vurdering af referenten:

(74) a. Sikke en dreng. Han løb ude i haven.

h. Sikke et træ. Det knækkede ude i haven.

i. Sikke et træ. Det blev væltet ude i haven.

j. Sikke et problem. Det opstod ude i haven.

Begrundelsessætningerne i (73) kan sammenlignes med begrænsende (definerende) relativsætninger i og med de ekspliciterer et identifikationsgrundlag, ikke for entiteter men for egenskaber. I modsætning hertil kan følgesætningerne i (74) tolkes parallelt til parentetiske relativsætninger.

Et sandsynligt alternativ til den første præmis er derfor at der kun er ekspletivt i de eksempler under (72) der svarer til (74), mens det er relativt i de tilfælde af (72) der svarer til (73). Vi får strukturen i (75)(a) for (72)(g), den i (b) for (72)(h):

(75) a

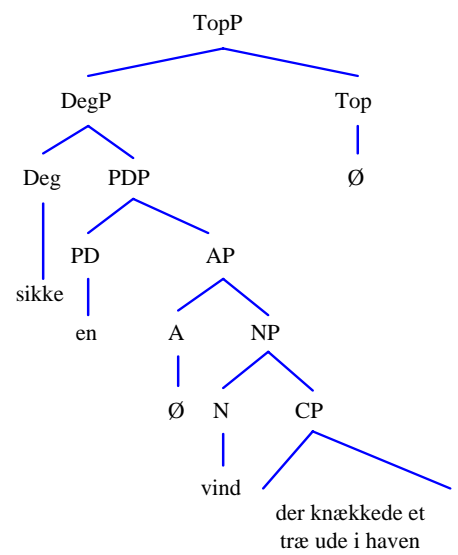

b.

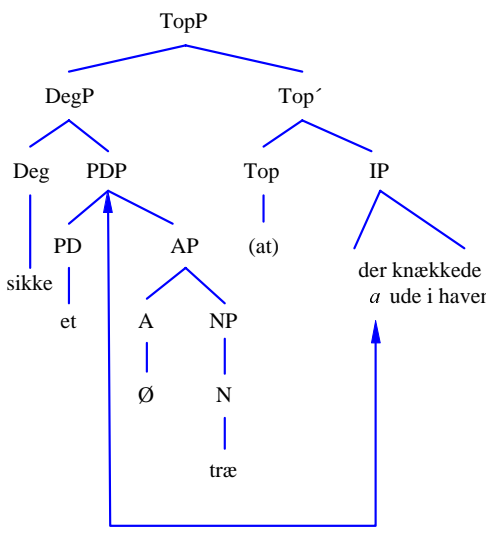


(75)(a) adskiller sig fra den (forkastede) løsning diskuteret under (6), idet der jo her ikke er tale om en relativisering af et objektsNP. Samtidig understreger den hvorfor der er så stor statistisk hyppighed af $X P$-udtryk som selvstændige ytringer. Der er tale om en specifikation af et samtaleemne: et XP-ydtryk satter blot et topic. For så vidt det rummer en prædikation - enten i form af en relativsætning eller en 'small clause' — udgør denne som begrundelsessætning blot identifikationsgrundlaget for det. En sådan begrundelsessætning ville også kunne optræde som selvstændig sætning.

Den anden præmis - at den associerede til et ekspletiv er et argument - anfægtes af Hatakeyama (1998), der argumenterer for at den associerede er et (eksplicit eller implicit) lokativt adverbial. I stedet for

(58) $\left[_{\mathrm{ES}}\right.$ Der] er ${ }_{\mathrm{a}}$ en flue] i min suppe

- foreslår han følgelig

(76) $\left[_{\mathrm{ES}}\right.$ Der] er en flue $\left[{ }_{\mathrm{a}} \mathrm{i}\right.$ min suppe]

Det er et intuitivt plausibelt forslag som under en række uafhængige antagelser tillige synes at være såvel strukturelt som semantisk velbegrundet. Set i vor sammenhæng sætter det yderligere fokus på forskellen imellem f. eks. (72)(a) og (b) hvis 'kilder' i (71) iflg. Vikner kan tilskrives verbernes forskellige egenskaber m.h.t. theta- og kasustilskrivning. Men de har også tydelige forskelle m.h.t. lokativ selektion.

Betragt endnu engang et par eksempler fra (72), gentaget her under (i), idet vi stadig indskrænker os til et enkelt repræsentativt verbum:

(77) i. a. Sikke en dreng der løb ude i haven

b. Sikke en dreng der grinede ude $i$ haven

ii. a. *Sikke en dreng ude i haven der løb

b. Sikke en dreng ude i haven der grinede

Verberne under (a) selekterer semantisk et lokativisk adjunkt, det gør verberne under (b) ikke. Følges Hatakeyama forklares ugrammatikaliteten i (ii)(a) under henvisning til at det ekspletive der ikke har nogen fortolkning fordi det mangler en associeret. Grammatikaliteten af (ii)(b), derimod, er en refleks af, at der her ikke er et ekspletiv, men et relativ. Både [en dreng ude i haven], konstrueret som 'small clause', og [der grinede] udgør tilsammen begrundelsesgrundlaget i form af CP-komplementet $\mathrm{i}$ en struktur som (75)(a), rekursivt indlejret i NP. 


\subsection{Knakstrukturer}

$X P$-udtryk er således at betragte som enstrengede strukturer, der specificerer en tom derivationsstreng. Det samme gælder $S$-udtryk med sikke som selvstændigt adverbium. I stedet for PredP som komplement ville de derimod tage CP. Dette ville give en uniform topic-analyse af samtlige sikke-udtryk, baseret på semantiske og kommunikative forhold. Tillægges strukturelle kriterier større vægt genereres denne type derimod efter (47)(c), som nævnt i fodnote 14. Andre $S$-udtryk, herunder ekspletive udtryk under sikke, er derimod hvad jeg vil kalde 'kncekstrukturer'. De er resultat af en derivation der kombinerer et enstrenget $X P$-udtryk med et enstrenget prædikativt udtryk hvormed det deler information via associationsrelationen. 'Knækket' sættes af TopP, der introducerer et medialt konjunktionselement der ikke kan være $\mathrm{V}$ (som det typisk ville være under $\mathrm{C}^{\circ}$ ). De to dele omtales som hhv. specifikatorstrengen $(=[\mathrm{Spec}, \mathrm{TopP}])$ og komplementstrengen $\left(=\left[\mathrm{Top}^{\prime}, \mathrm{Compl}\right]\right)$. Den information der deles imellem de to strenge vil herefter normalt optræde eksplicit i specifikatorstrengen, implicit i associerede knuder på forskellige positioner i komplementstrengen.

Som det fremgår af (14) - og på trods af fodnote 4 - akcepteredes Delsings (1993) interne analyse af DP, med NP som højre-specifikator i AP. Det blev endvidere påpeget i 3.2.1. at AP indgår i PDP. Nærmere diskussion af disse valg følger her. Sammenlign

(78) a. sikke en kuffert han har på loftet. Den er vel nok \{let $\mid$ flot $\mid$ gammel | mølædt $\mid *$ fransk $\mid$ etc. $\}$

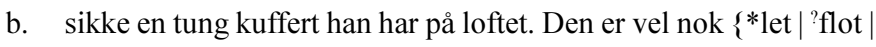
?gammel | 'mølædt |*fransk | etc.

I (a) udtrykkes talers vurdering af et situeret træk ved en genstand klassificeret som 'kuffert', og der er i begrundelsessætningen frit slag m.h.t. hvilken egenskab ved den man lægger til grund, så længe der er tale om en accidental egenskab. I (b) derimod er det udelukkende talers vurdering af vegten af kufferten, og de anførte begrundelsessætninger vil være ubeføjede i forskellig grad. Antages Delsings struktur kan dette forhold nemt forklares ved at sikke har skopus over den ncermeste leksikalske kerne; og den nærmeste leksikalske kerne er altid $\mathrm{A}$, selv når den ikke er realiseret: 


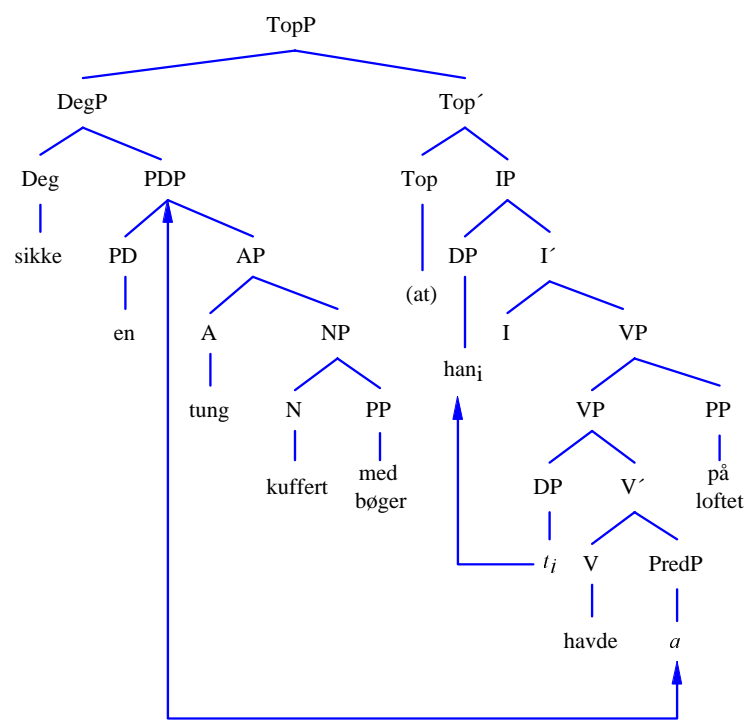

Jeg sagde at delt information normalt var eksplicit i specifikatorstrenge, implicit i komplementstrenge. Det behøver ikke altid være tilfældet. Bemærk først at en lokativ PP semantisk selekteret af V ikke kan optræde i specifikatorstrengen:

(80) a. *sikke [en tung kuffert på loftet] han har

Det kan derimod en komitativ PP selekteret af N:

b. sikke [en tung kuffert med gamle bøger] han har på loftet

En sådan PP kan slutstilles ((c), (d)), muligvis efter sædvanlige tungtledsprincipper (e):

c. sikke [en tung kuffert [ ] han har på loftet [ [ [med gamle bøger]]

d. *sikke [en tung kuffert [ ]] han har [ [med gamle bøger]] på loftet

e. 'sikke [en tung kuffert [ ] han har [ [a [med bøger]] på loftet

Men det gælder også for PP-komplementer til adjektiver:

(81) a. sikke [glad for piger] han er $\left[{ }_{a}\right]$

b. sikke [glad [ ]] han er [ [ for piger]]

Her er der næppe tale om tungtledseffekten. Specielt (81) udgør således mulig empirisk evidens imod association til fordel for flytning. 


\subsubsection{Strukturel topikalisering: $T o p P$ vs. $C P$}

Det ville styrke beskrivelsen af $S$-udtryk hvis det kunne godtgøres at også andre konstruktioner lod sig beskrive som knækstrukturer. I betragtning af sikke-udtryks kategoriale status er et nærliggende udgangspunkt at se på andre akcepterede former for eksklamation og topikalisering.

$S$-udtryk er talesprogets foretrukne variant af eksklamative udtryk, men der er $H V$-varianter:

(82) a. Hvor stor du er blevet!

b. Hvilken arrogance de udviste!

c. Hvilken forsamling af spytslikkere der altid omgiver ham

Som i $S$-udtryk er der heller ikke her V2 - med V2 ville der være tale om spørgsmål, og dermed om normale CPer med HV-flytning, idet der dog i (c) ikke ville være noget ekspletiv. Men (82) udviser præcis de samme træk som $S$-udtryk m.h.t. ordstilling og indsætning af ekspletiv. Det ville derfor være naturligt at behandle dem derivationsmæssigt ens som knækstrukturer. HV-udtryk adskiller sig herefter fra $S$-udtryk ved blot at have DP — i stedet for DegP — som [Spec,TopP].

Det er almindeligt anerkendt at dansk tillader hvad jeg vil kalde kommunikativ topikalisering af alle infinite konstituenter i CP. Strukturelt set kan der (bl. a.) være tale om flytning af hhv. subjekt, objekt og indirekte objekt til [Spec,CP]. Til hver af sætningerne i (83)(i) svarer strukturen i (ii):

$$
\begin{aligned}
& \text { i. a. Per gav sin søn den cykel } \\
& \text { b. Den cykel gav Per sin søn } \\
& \text { c. Sin søn gav Per den cykel }
\end{aligned}
$$

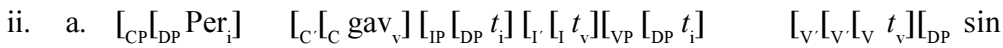

En anden form for emfatisk topikalisering opnås ved Det-kløvning, en konstruktion som Nølke (1984) har underkastet en nøjere GB-analyse med særligt henblik på dansk. Nølkes resultater er helt forenelige med de forslag der fremlægges her, idet han dog ikke anerkender TopP som 
den særlige kategori hvorom det her drejer sig og altså heller ikke opererer med den specielle knækstruktur som jeg vil argumentere for.

(84) a. Det var Per der gav sin søn den cykel

b. Det var den cykel (at) Per gav sin søn

c. Det var sin søn (at) Per gav den cykel

Parentesen omkring at her skal antyde at det ikke er en normal form i standard dansk (skriftsprog), men at den hyppigt forekommer i almindeligt talesprog. Forskellen imellem de to topikaliseringsformer i (83) og (84) svarer til skellet imellem prædikation og eksklamation, som ovenfor er lagt til grund for hhv. CP og TopP stukturer. Forskellen imellem sikke-strukturer og (84) er bl.a. bestemthed i det følgende NP. Hvor sikkeudtryk satter et topic, fremhæver en Det-kløvning et allerede sat topic. Min påstand er m.a.o. at der bag f. eks. (84)(c) ligger en struktur som:

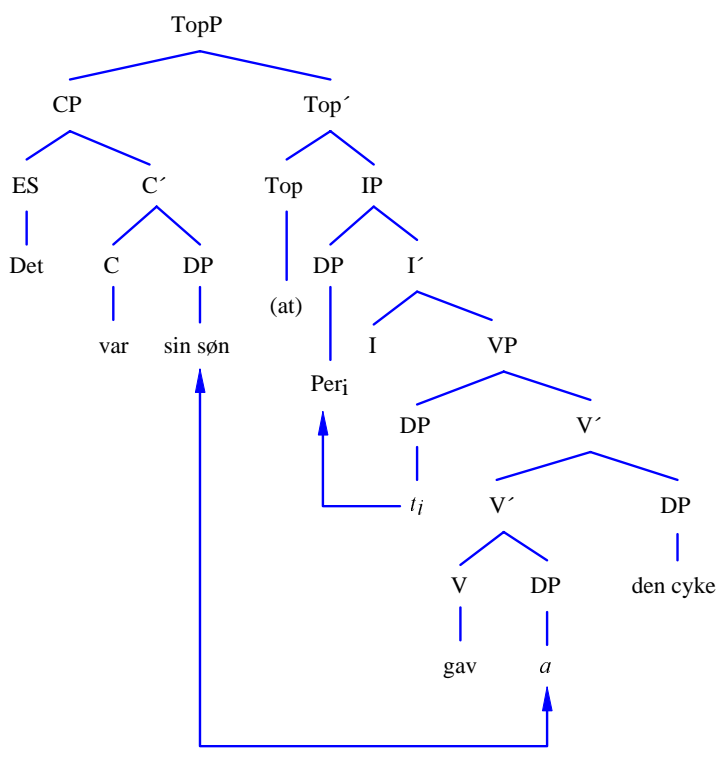

Under sædvanlige antagelser om en 'clause-mate' begrænsning på forekomsten af sig og sin er det klart at Det var sin søn må dele anaforisk domæne med Per. Det illustreres klart i et 'minimalt par' som:

(86) a. Det var $\left[\sin _{\mathrm{i}} / \mathrm{hans}_{\mathrm{j}} \mathrm{søn}\right]_{\mathrm{k}}$ (at) $\mathrm{Per}_{\mathrm{i}}$ slog fordi han $\mathrm{i}_{\mathrm{i} j \mathrm{k} / \mathrm{l}}$ græd

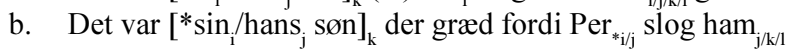


I begge tilfælde er der tale om knækstrukturer. I (86)(a) er Per subjekt i komplementstrengen og derfor 'clause-mate' med komplementet til var. I (86)(b), derimod, er (ekspletivt) der subjekt i komplementstrengen, mens Per er subjekt i en underordnet sætning. Konstruktionsformen i (86)(b) er dermed helt parallel til (75)(b).

Nølke (1984:78f) påpeger at det kun er maksimale projektioner der kan optræde som (det han kalder) 'focus' (svarende til det understregede element i Det var sin søn han gav en cykel) i Det-kløvninger. I (85) er fokus komplement i en tilsyneladende stærkt reduceret CP i rollen som [Spec, TopP]. Den er dog kun her reduceret af bekvemmelighedshensyn. Der er tale om en fuldvoksen CP, der imidlertid er underlagt den begrænsning altid at have Det som specifikator, og en finit form af vare eller blive som V. Det betyder m.a.o. at fokus kan udgøres af de maksimale projektioner der kan selekteres af disse to verber. Med de begrænsninger der er pålagt af bestemthedsklausulen er det præcis de samme som kan selekteres af sikke. Og her er der en interessant rekursion, som understøtter den enstrengede analyse af $S$-udtryk med sikke som selvstændigt adverbial der blev skitseret $i$ afsnit 3.5. Det viser sig nemlig at vi blandt disse finder CP (eksempler fra Nølke (1984:79), men med intrapolerede negationer i rund parentes og annoterede klammer):

(87) a. $\left[_{\text {Top }}\left[{ }_{C P}\right.\right.$ Det $\left[_{C}\right.$ er $]\left[_{C P}\left[{ }_{C}\right.\right.$ fordi] du ryger $\left.]\right]$ jeg ikke kan holde dig ud]

b. $\left[_{\text {TopP }}\left[_{C P}\right.\right.$ Det $\left[_{C}\right.$ er] kun $\left[{ }_{C P}[\right.$ når $]$ solen skinner $\left.]\right]$ vi (ikke) tager på landet $]$

c. $\quad_{\text {TopP }}\left[_{C P} \operatorname{Det}\left[_{C}\right.\right.$ er $]\left[_{C P}\left[_{\text {Spec }}\right.\right.$ dét $]\left[_{C}\right.$ at du ikke svarer mig] $\left.]\right]$, jeg (ikke) bliver sur over]

De intrapolerede negationer skal understrege at der i hvert tilfælde er tale om den forventede ledsætningsordstilling som vi kender fra komplementstrengen i sikke-udtryk. Kun i (b) er højreadjungeret til $\left[_{\mathrm{C}} \mathrm{er}\right]$, efter helt de samme retningslinjer som dog efter sikke.

Hvis der som påstået er tale om en fuldvoksen CP i [Spec,TopP] bør vi bl.a. kunne finde eksempler på kommunikativ topikalisering inden for den, og altså finde udtryk der kombinerer kommunikativ med strukturel topikalisation. Det er tydeligvis tilfældet. Betragt følgende:

(88) a. Der var en mand fra Polen $\left\{\right.$ som $\left.|\operatorname{der}| \operatorname{som} \operatorname{der} \mid{ }^{*} \varnothing\right\}$ kendte dig

b. Dig var der en mand fra Polen $\left\{{ }^{*} \operatorname{som}|\operatorname{der}| \operatorname{som} \operatorname{der} \mid{ }^{*} \varnothing\right\}$ kendte

c. Der var en mand fra Polen $\{$ som $\mid *$ der $\mid *$ som der $\mid \varnothing\}$ du kendte

Selvom tolkningen af der ikke kan være ekspletivt ( *Der kendte en mand fra Polen dig), er der i alle tre tilfælde tale om strukturel topikalisering, 
som antydet af en række forskelligheder m.h.t. valg af relativ. I (a) er der fri variation imellem relativerne som og der, og der kan i dagligsproget forekomme dobbelt relativ. I (b), derimod, vurderes det at som alene er udelukket, men at det kan forekomme som første del af en dobbelt relativ. I hverken (a) eller (b) kan relativet helt udelades. I (c) kan der ikke forekomme, hverken alene eller som anden del af en dobbelt relativ. Derimod kan relativet helt udelades. Dette er en helt normal distribution af relativpronominer i dansk ved hhv. subjekts- og objektsrelativisering. Derudover adskiller (b) sig fra (a) ved at have kommunikativ topikalisering af dig. Strukturelle beskrivelser der indfanger disse forhold ville være følgende:

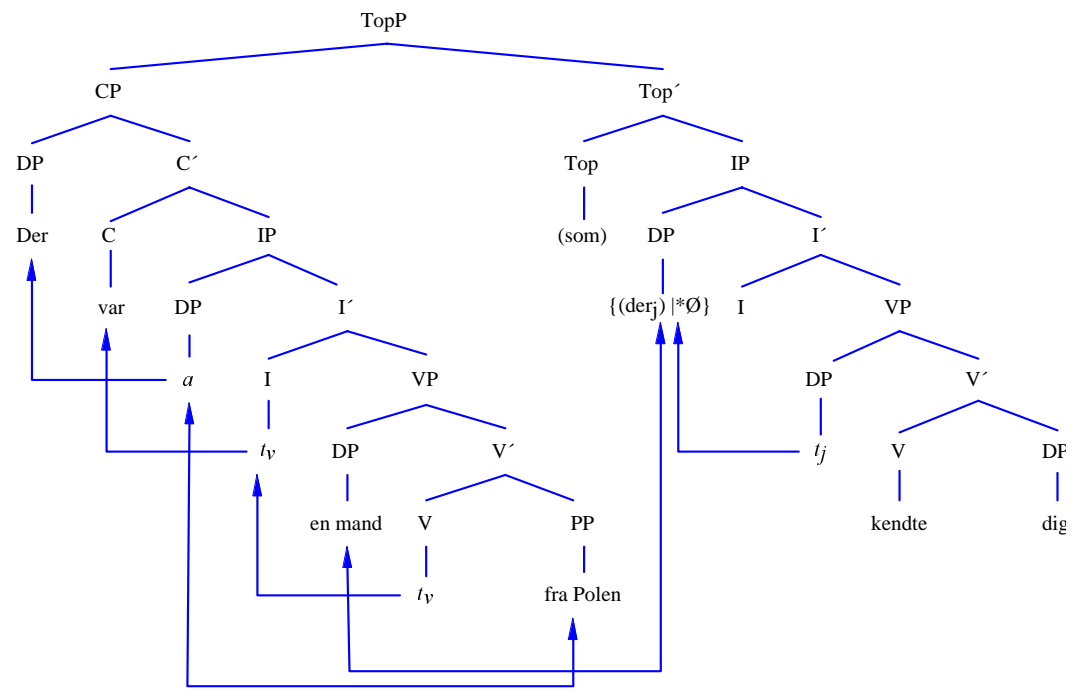


b. TopP

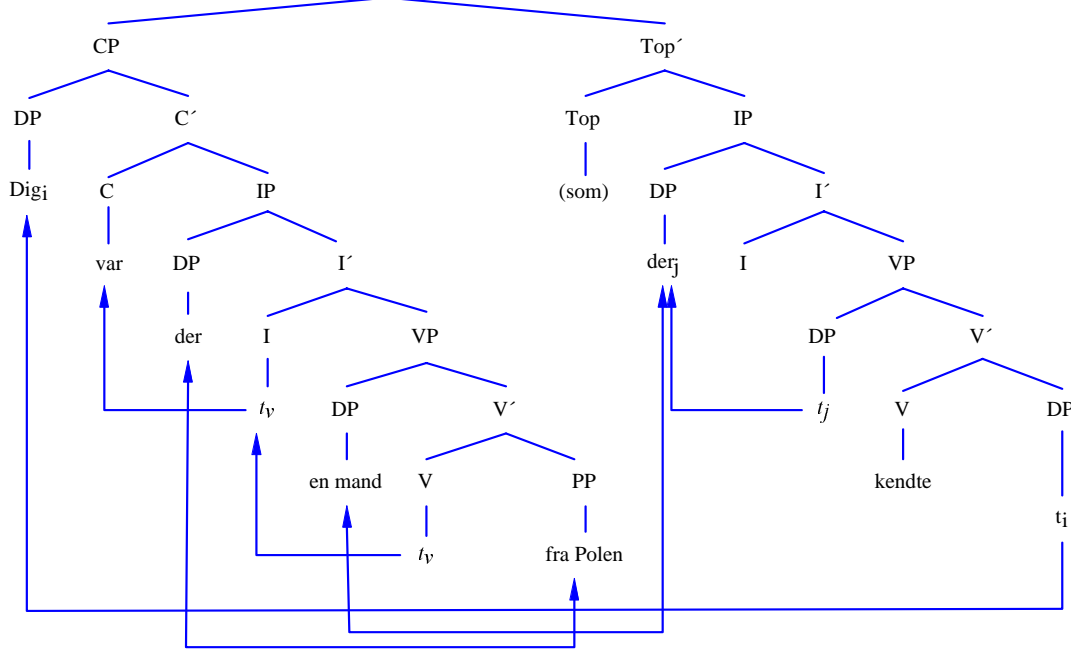

c.

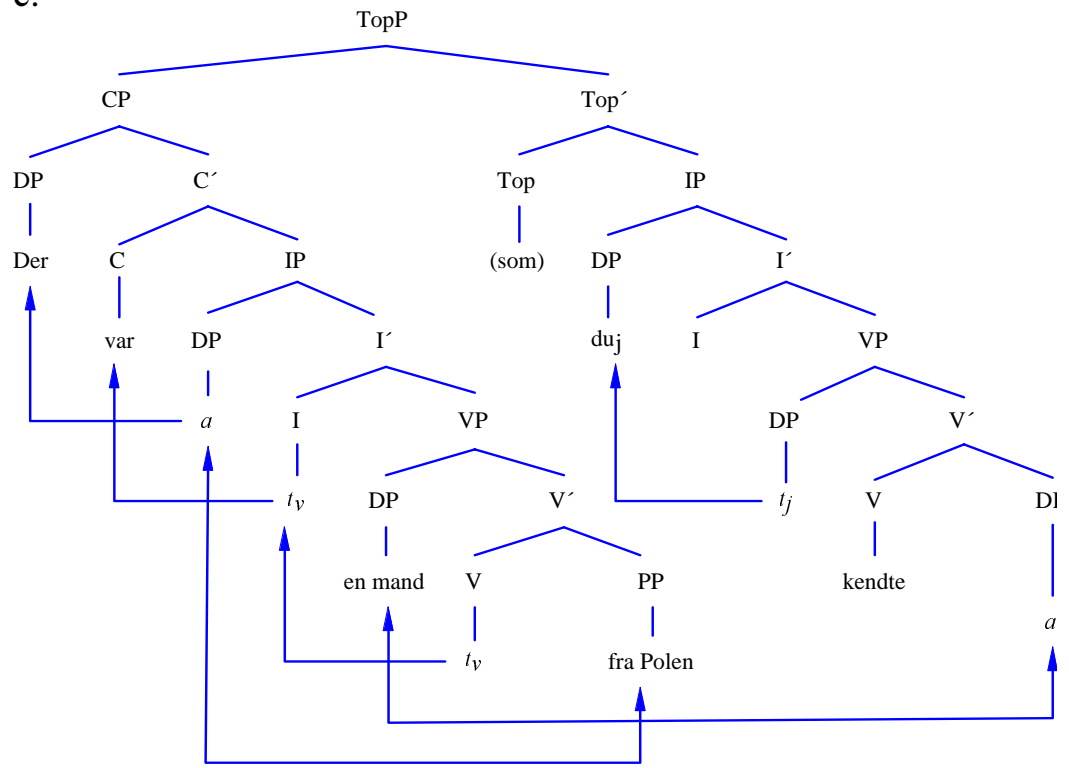


I alle tre tilfælde udgør specifikatorstrengen som forventet en ekspletiv konstruktion i form af en CP. Samtidig sætter den i hvert tilfælde det topic komplementstrengen prædicerer om. Bemærk at det $\mathrm{i}$ alle tre tilfælde ville være muligt at ophæve bestemthedsklausulen fra en mand:

(90) a. Der var den mand fra Polen $\left\{\operatorname{som}|\operatorname{der}| \operatorname{som} \operatorname{der} \mid{ }^{*} \emptyset\right\}$ kendte dig

b. Dig var der den mand fra Polen $\left\{{ }^{*}\right.$ som $\mid$ der $\mid$ som der $\left.\mid{ }^{*} \varnothing\right\}$ kendte

c. Der var den mand fra Polen $\{\operatorname{som}|* \operatorname{der}| * \operatorname{som} \operatorname{der} \mid \varnothing\}$ du kendte

Dette ville medføre en rekategorisering af strukturerne i (89) til enstrengede CP'er, af tolkningen af [den mand + fra Polen] som 'small clause' komplement til [ $\left.{ }_{\mathrm{V}} \mathrm{var}\right]$, og med de identificerende relativsætninger adjungeret til [den mand]. Resultatet ville blive simple lokativsætninger.

\subsubsection{Leksikaliseret aspekt}

Ekspletive konstruktioner blev ovenfor i afsnit 3.4. udnævnt til at være de prædikative (CP) modstykker til $S$-udtryk (TopP). Det blev ligeledes nævnt at der er en mulig undtagelse fra denne generelle regel. Omtalen af den følger her.

Der er en lille gruppe af verber, næsten sammenfaldende med dem i (71)(a), der har den særlige grammatiske egenskab at leksikalisere progressivt aspekt i en tilsyneladende koordineret struktur:

(91) Der gik en mand og rodede ude i haven

Der er, som det fremgår, tale om en ekspletiv konstruktion, ikke kløvning. Den er underlagt bestemthedsklausulen, og den opfører sig ikke syntaktisk som normale koordinationer:

(92) a. *Der gik manden og rodede ude i haven (naturligvis akceptabel med lokativt dér)

b *Der gik en mand og han rodede ude i haven

c. *Der rodede en mand ude i haven og han gik

d. *Der gik, rodede og rev en mand ude i haven

e. *Der gik en mand $\{$ men $\mid$ eller\} rodede ude i haven

Man kunne tentativt foreslå en (simplificeret) struktur som: 
(93)

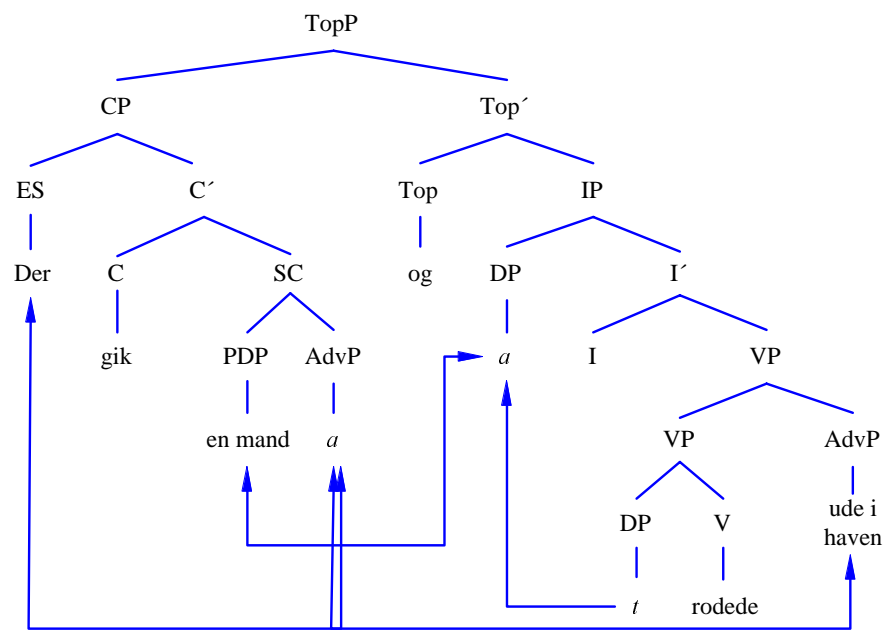

Hvis det fastholdes at alle ekspletive konstruktioner er CP'er er (93) ikke korrekt. Men så må der gives en anden forklaring på de særlige leksikaliseringsformer af progressivt aspekt, en forklaring der tager hensyn til deres specielle begrænsninger $\mathrm{i}$ forhold til andre koordinerede strukturer. Derudover er der et argument for (93) i det klare tilfælde af informationsdeling der foreligger imellem de to AdvP'er:

(94) a. Der gik en mand og rodede ude i haven $(=(91)(a))$

b. Der gik en mand ude i haven og rodede

c. *Der gik en mand ude $i$ haven og rodede ude i haven

d. *Der gik en mand ude i haven og rodede nede i kælderen

e. Der gik en mand ude i haven og rodede med nogle stauder

f. Der gik en mand og rodede med nogle stauder ude i haven

Her er (a) og (b) (sandhedsfunktionelt) identiske, (c) tautologisk, (d) kontradiktorisk, (e) og (f) igen (sandhedsfunktionelt) identiske. Den logiske status af (c) og (d) lader sig formentlig kun forklare ved at lokaliteten for agenten for gik nødvendigvis er den samme som lokaliteten for agenten for rodede. Det er den samme situation der beskrives i de to 'sætninger' med hhv. gik og rodede som V, men den første sætter blot et topic, som den anden prædicerer om. Sml. (94)(c) og (d) med følgende:

(95) a. Peter går ude $\mathrm{i}$ haven og roder ude $\mathrm{i}$ haven og spiser ude $\mathrm{i}$ haven og ...

b. Peter går ude i haven og roder nede i kælderen og spiser oppe på loftet .... 
Der er ikke noget tautologisk eller kontradiktorisk over disse, blot fremtvinger de en fuldverbums, ikke-progressiv, habituel læsning af de involverede verber. De er normale koordinationer.

Derivationen i (93) er naturligvis ikke forbeholdt ekspletive konstruktioner. En helt parallel struktur ville gælde for progressive modstykker til (95):
a. Peter går ude $\mathrm{i}$ haven og roder
b. Peter sidder og spiser oppe på loftet

Det er simpelthen den knækstrukturelle mulighed dansk udnytter i forbindelse med leksikaliseringen af progressiv.

\section{Konklusion}

Det har været mit hovedærinde at gøre rede for de morfologiske, semantiske og distributionelle forhold ved sikke-udtryk af alle afskygninger. De har hidtil unddraget sig systematisk behandling, og de udviser da også en række træk der ikke er forenelige med gængse analyser af danske kernekonstruktioner. Ikke desto mindre viser det sig at de - naturligvis - er underlagt ganske præcise begrænsninger.

Den afgørende forudsætning for at nå frem til dem er erkendelsen af at der i dansk undertiden optræder en medial konjunktionallignende størrelse hvis realisation kan være af forskellig art (at, og, som og prosodisk brud i talesprog, at og komma i skriftsprog). Dermed banes vejen for at betragte en CP-struktur som derivationelt 'knækket' i to dele, eller strenge, der deler information på designerede positioner. Dermed 'rekategoriseres' en CP til en Top(ic) P(hrase), en kategori hvis kommunikative funktion primært er at satte et topic snarere end at udsige noget om det. Støtte for denne strukturelle rekategorisering søgtes bl.a. i Strawsons intuitive påberåbelse af 'feature placing statements' - udtryk hvis funktion netop er at instantiere et (universelt) 'træk' som diskurselement. Endelig blev der søgt empirisk støtte for analysen af sikke-udtryk i antagelsen om at også andre danske konstruktionstyper (HV-udråb, Det-kløvning, visse komplekse ekspletive udtryk samt leksikaliserede aspektudtryk) ville kunne analyseres under de samme antagelser, nærmere bestemt som komplekser af eksklamative og prædicerende udtryk. Den foreslåede analyse giver en meget klar begrundelse for det empiriske faktum at de her benævnte $X P$-udtryk, der udgør over halvdelen af de registrerede sikke- 
udtryk i et datamateriale på ialt 138 forekomster, fremstår som prædikatsløse udråb snarere end prædikationer, idet de er realisationer af kun den ene af de to involverede derivationsstrenge. Resten - de her benævnte $S$-udtryk — er, som de øvrige konstruktionstyper, komplekser af eksklamation og prædikation, der udnytter begge strenge.

Prisen kan forekomme høj — nemlig en slækkelse af i øvrigt veldokumenterede begrænsninger på informationsdeling (i form af flytningsprincipper). Mest iøjnefaldende er slækkelsen af 'c-kommando klausulen', der udelukker komplementpositioner som landingsplads for flyttede konstituenter. Imidlertid forekommer der ret tungtvejende empiriske grunde til at supplere flytning med en anden form for informationsdelingsmekanisme, der i øvrigt allerede udnyttes, nemlig associationsrelationen som den formodes at holde imellem et ekspletiv og et indholdssubjekt.

Endelig skal man betænke at vi jo netop har at gøre med en 'perifer' konstruktionstype. Hvis den uden videre kunne indpasses i akcepterede analysemønstre ville den netop ikke være 'perifer'. Hvor langt man kan gå i retning af at løsne op for principper der for længst er etableret som begrænsende for analysen af 'kernekonstruktioner' er dernæst et andet spørgsmål. Men det har, som alt andet, formentlig et svar der primært skal dikteres af empiriske og deskriptive hensyn.

\section{Litteraturhenvisninger}

Abney, P. S. (1987). The English Noun Phrase in its Sentential Aspect. Unpubl. Ph. D. thesis. Cambridge, Mass., MIT.

Allan, R., P. Holmes, \& T. Lundskær-Nielsen. (1995). Danish: A Comprehensive Grammar. London, Routledge.

Anderson, J. M. (1971). The Grammar of Case. Cambridge, Cambridge University Press.

Anderson, J. M. (1977). On Case Grammar. London, Croom Helm.

Anderson, J. M. (1997). A Notional Theory of Syntactic Categories. Cambridge, Cambridge University Press.

Basbøll, H. (1986). "Diderichsen vs. Dik eller Feltanalyse vs. Funktionel grammatik." In Nydanske studier \& Almen kommunikationsteori 16-17 (Særhæfte: Satningsskemaet og dets stilling - 50 år efter). Pp. 56-76.

Bergenholtz, H. DK87/90. Dansk tekstkorpus. København, Det danske sprog- og litteraturselskab.

Boškoviè, Z. (1997). The syntax of nonfinite complementation. An economy approach. Cambridge, Mass., MIT. 
Bowers, J. (1993). “The syntax of predication.” In Linguistic Inquiry 24, pp. 591-656.

Burzio, L. (1986). Italian Syntax. Dordrecht, Reidel.

Chomsky, N. (1986). Barriers. Cambridge, Mass., MIT.

Chomsky, N. (1991). Economy of Derivations and Representation. In The Minimalist Program. Cambridge, Mass., MIT. 1995. Pp. 129-166.

Chomsky, N. (1995). The Minimalist Program. Cambr. Mass., MIT Press.

Culicover, P. W. \& R. S. Jackendoff(1999). “The View from the Periphery: The English Comparative Correlative." In Linguistic Inquiry 30, pp. 543-571.

Delsing, L.-O. (1993). The Internal Structure of Noun Phrases in the Scandinavian Languages: A Comparative Study. Lund, University of Lund.

Diderichsen, P. (1935-6). “Dansk Sætningsanalyse. Dens Formål og Metode.” In Nydanske studier \& Almen kommunikationsteori. 16-17. 1986. (Særhæfte: Scetningsskemaet og dets stilling - 50 år efter). Pp. 7-17.

Fischer-Hansen, B. \& A. Kledal (1994). Grammatikken: Håndbog i dansk grammatik for udlcendinge, Social-Pædagogisk Forlag.

Hansen, E. (1980). Domonernes Port. København, Reitzel.

Hansen, E. (1983). "Det Pleonastiske At." Danske Studier: 61-80.

Hatakeyama, Y. (1998). "There-Existential Sentences: What Replaces the Expletive There at LF?" In Linguistic Analysis 28, pp. 227-251.

Heltoft, L. (1999). Hierarki og rækkefølge — skandinavisk ledstilling i funktionel grammatisk betydning. In P. A. Jensen \& P. R. Skadhauge (udg.) Scetningsskemaet $i$ generativ grammatik. Kolding, Inst. for Erhvervssproglig Informatik og Kommunikation, Syddansk Universitet. Pp. 31-62.

Herslund, M. (1984). "Particles, Prefixes and Preposition Stranding." In Nydanske Studier 14 (Særhæfte: Topics in Danish Syntax), pp. 34-71.

Herslund, M. (1986). The double object construction in Danish. In L. Hellan \& K. K. Christensen (udg.) Topics in Scandinavian Syntax. Dordrecht, Reidel. Pp. 125-147.

Johnson, K. (1991). “Object positions.” In Natural Language and Linguistic Theory 9, pp. 577-636.

Kay, P. \& C. J. Fillmore (1999). "Grammatical constructions and Linguistic Generalizations: The What's $X$ doing $Y$ ? Construction." In Language 75 (1), pp. 1-33.

Larson, R. (1988). “On the double object construction.” In Linguistic Inquiry 19, pp. 335-91.

Larson, R. (1990). "Double objects revisited:reply to Jackendoff.” In Linguistic Inquiry 22, pp. 589-632.

Lasnik, H. (1999). "On Feature Strength: Three Minimalist Appoaches to Overt Movement." In Linguistic Inquiry 30, pp. 197-217.

Mikkelsen, K. (1911). Dansk Ordføjningslare. København, Hans Reitzel (1975). 
Milsark, G. L. (1977). "Towards an explanation of certain peculiarities in the existential construction in English.” In Linguistic Analysis 3, pp. 1-30.

Nølke, H. (1984). “Clefting in Danish?” In NyS 14 (Særhæfte: Topics in Danish Syntax), pp. 72-111.

Pollard, C. \& I. Sag (1994). Head-Driven Phrase Structure Grammar. Chicago \& London, University of Chicago Press.

Radford, A. (1993). Head-hunting: On the trail of the nominal Janus. In G. G. Corbett, N. M. Fraser \& S. McGlashan (udg.) Heads in grammatical theory. Cambridge University Press. Pp. 73-113.

Radford, A. (1997). Syntactic theory and the structure of English: A minimalist approach. Cambridge University Press.

Riemsdijk, H. v. (1978). A Case Study in Syntactic Markedness. The Binding Nature of Prepositional Phrases. Dordrecht, Reidel.

Rizzi, L. (1990). Relativized Minimality. Cambridge, Mass., MIT.

Sigurdsson, H. A. (1996). "Icelandig Finite Verb Agreement." In Working Papers in Scandinavian Syntax 57, pp. 1-46.

Strawson, P. F. (1959). Individuals: An Essay in Descriptive Metaphysics. London, Methuen, 1974.

Vikner, S. (1995). Verb Movement and Expletive Subjects in the Germanic Languages. Oxford, Oxford University Press.

Vikner, S. (1999). Ledstillingen i dansk og government \& binding. In P. A. Jensen \& P. R. Skadhauge (udg.) Scetningsskemaet og generativ grammatik. Kolding, Institut for Erhvervssproglig Informatik og Kommunikation, Syddansk Universitet. Pp. 83-110.

Zamparelli, R. (1996). Introduction to Layers in DP, http://www.cogsci.ed.ac.uk/ roberto/ layers/intro.html. 


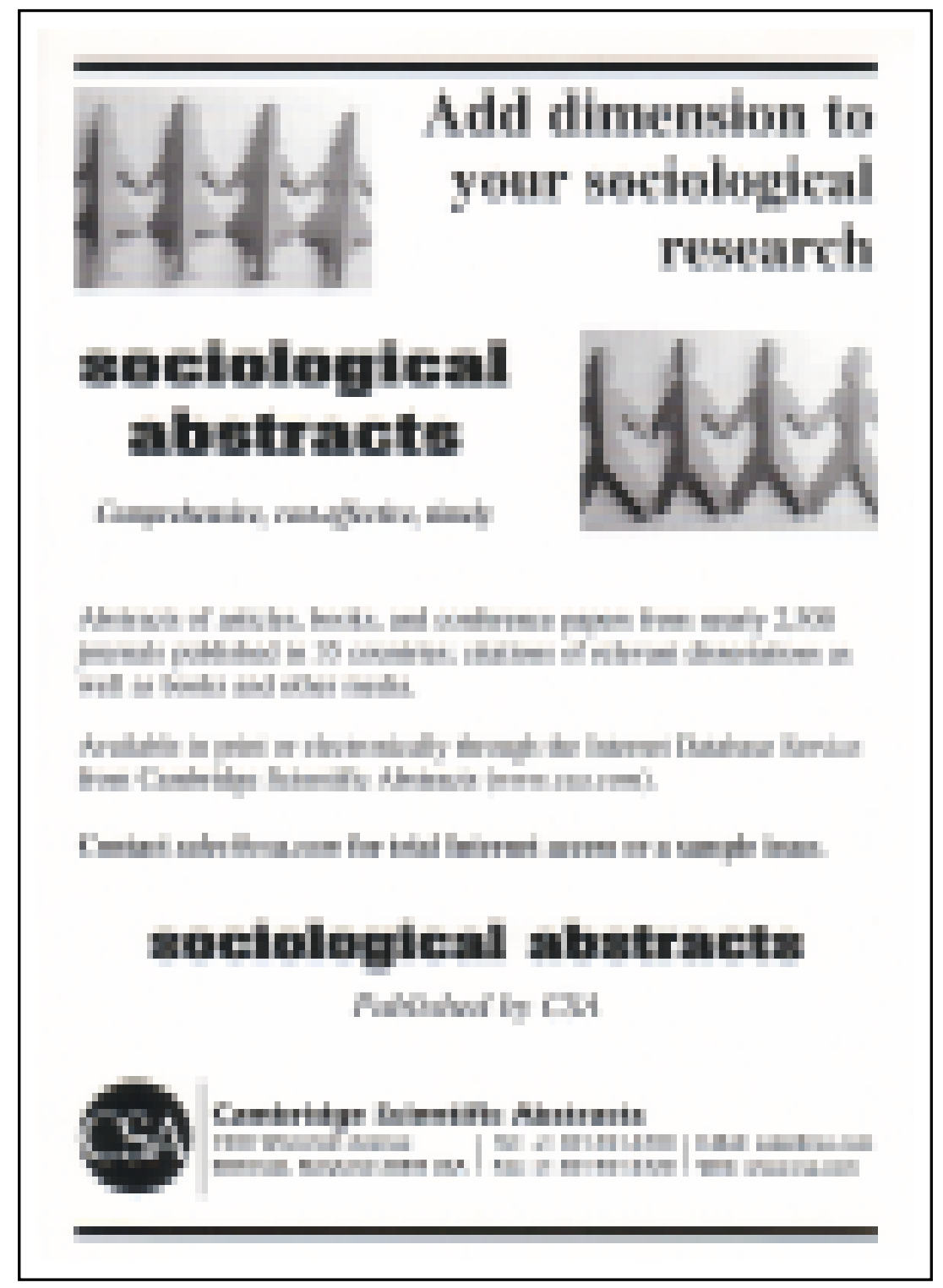

